\title{
WILDLIFE ASSESSMENT OF THE CHANDRAGIRI HILLS, KATHMANDU: POTENTIAL FOR ECOTOURISM
}

\author{
Hem Bahadur Katumal ${ }^{1,2,3 *}$, Hari Basnet ${ }^{3}$, Hari Prasad Sharma ${ }^{4}$, Sabina Koirala ${ }^{2,3,5}$, \\ Bhaiya Khanal $^{6}$, Kaustuv Raj Neupane ${ }^{3,7}$, Kul Bahadur Thapa ${ }^{8}$, Dibas Babu Panta ${ }^{9,10}$, \\ Kanchan Parajuli ${ }^{3}$, Sandesh Lamichhane ${ }^{3,11}$, Mangkal Rai ${ }^{3}$, Tejab Pun ${ }^{3}$, Shruti Shakya ${ }^{4}$ \\ AND SURAJ BARAL ${ }^{3}$ \\ ${ }^{1}$ Center for Integrative Conservation, Xishuangbanna Tropical Botanical Garden, \\ Chinese Academy of Sciences, Mengla, Yunnan, China \\ ${ }^{2}$ University of Chinese Academy of Sciences, Beijing, China \\ ${ }^{3}$ Small Mammals Conservation and Research Foundation, Kathmandu, Nepal \\ ${ }^{4}$ Central Department of Zoology, Institute of Science and Technology, Tribhuvan University, \\ Kirtipur, Kathmandu, Nepal \\ ${ }^{5}$ Institute of Zoology, Chinese Academy of Sciences, Chaoyang, Beijing, China \\ ${ }^{6}$ Natural History Museum, Tribhuvan University, Swyombhu, Kathmandu, Nepal \\ ${ }^{7}$ Department of Zoology, Trichandra Multiple Campus, Tribhuvan University, Kathmandu, Nepal \\ ${ }^{8}$ Himalayan Nature, Lazimpat, Kathmandu, Nepal \\ ${ }^{9}$ Central Department of Environmental Science, Tribhuvan University, Kirtipur, Kathmandu, Nepal \\ ${ }^{10}$ Master of Project Management, University of Technology, Sydney Australia \\ ${ }^{11}$ Institute of Forestry, Office of the Dean, School of Forestry and NRM, Kathmandu, Nepal
}

\begin{abstract}
.
Wildlife assessments can provide crucial information regarding species richness, relative abundance and spatial, temporal, and ecological information on wildlife habitat associations. The assessment's information can in turn be used for developing management policies including for establishing touristic zones. We investigated wildlife occurrences in the Chandragiri Hills, Kathmandu Nepal from 2015-2019 to provide baseline data to inform the potential sites for ecotourism. During the study period, we recorded 30 mammal species, 199 bird species, 34 herpetofauna species and 77 butterfly species. The area harbors three globally and six nationally threatened mammal species, two globally and seven nationally threatened with one endemic bird species, one globally and nationally threatened herpetofauna, and one nationally threatened butterfly species. We also explored four potential hiking routes for observing wildlife and providing scenic views of the Himalayan range and Kathmandu city. Therefore, we expect Chandragiri Hills can become one of the hot spot for tourists to observe both common and threatened wildlife species in Nepal.
\end{abstract}

Key words: bird; butterfly; herpetofauna; mammal; hiking route; threatened species.

\section{INTRODUCTION}

Wildlife assessments provide critical data on species richness, abundance and spatial, temporal and ecological knowledge of their habitat (Katuwal et al. 2018). Assessments can be used to analyze the conservation status of species and to develop conservation action programs (Thomas 1982; Inskipp et al. 2016). In addition, data from assessments can benefit wildlife tourism through increased knowledge and potential observations. Increased tourists flow can also increase employment opportunities for local people and communities. Therefore, nature-based tourism is an emerging industry in developing coun- tries, supporting nature conservation and the well-being of local people (Donohoe and Needham 2006). Hence, wildlife becomes an integral part of ecotourism as people are demonstrating increased interest towards wildlife-based tourism (Cong et al. 2014).

The Nepal government has established protected areas comprising about $24 \%$ of the total land area, including National Parks, Wildlife Reserve, Hunting Reserve, Conservation Areas and Cultural Heritage sites to conserve wildlife and enhance ecotourism (Baral et al. 2012). Most of these protected areas are in lowland and high land physiographic regions with few exceptional areas in the mid-hills region 
of Nepal (DNPWC 2018). Wildlife in protected areas of Nepal are well known (Jnawali et al. 2011; Inskipp et al. 2016) and ecotourism has occurred for decades (see Bookbinder et al. 1998). However, there are many other potential sites outside the existing protected areas, especially in mid-hills like near to Kathmandu Valley (e.g., Phulchoki Mountain Forest) with diverse wildlife and natural beauty (Baral and Inskipp 2005; Jnawali et al. 2011; Katuwal et al. 2018). These places are more popular as weekend destinations for tourists. The Chandragiri Hills, which occur in the mid-hills region southwest of Kathmandu Valley, has similar topography and vegetation to Shivapuri-Nagarjun National Park and Phulchoki Mountain Forest, and is expected to have diverse wildlife. However, a wildlife assessment has not yet been conducted in the Chandragiri Hills and the current information of wildlife is little known.

We conducted a baseline assessment of wildlife in the Chandragiri Hills to understand the potential for ecotourism near to Kathmandu, the capital city of Nepal. We emphasized our assessment on mammal, bird, herpetofauna, and butterfly species along potential hiking routes. This assessment will provide a baseline data for conserving common and threatened species in this area (e.g., Higginbottom and Tribe 2004; Larm et al. 2018), which potentially may improve local livelihoods (KC et al. 2015), and strengthens local guardianship of endangered species and their habitats (Bookbinder et al. 1998).

\section{Materials and Methods 1.1. Study area}

We conducted this study in Chandragiri Hills (Figure 1), comprising about $11 \mathrm{~km}^{2}\left(27.6672^{\circ} \mathrm{N}\right.$, $85.2058^{\circ} \mathrm{E}$ ) in Chandragiri Municipality, Kathman$\mathrm{du}$, Nepal, with an elevational range of 1300 to 2540 $\mathrm{m}$. The Chandragiri Hills is about $16 \mathrm{~km}$ far from the core area of the Kathmandu city and is connected with major road with regular bus services. It is an historical place from where the Late King Prithivi Narayan Shah, the unifier of the Nepal Kingdom, had designed a military attack on the Kathmandu Valley during the $18^{\text {th }}$ century. The cable car is operating since December 2016. The area is also famous for visiting the Bhaleshwor Mahadev temple which lies at the top of the Hills, with views of the Kathmandu Valley and Himalayan Range. The climate is sub-tropical to temperate which influences the occurrence of mixed vegetation including Alnus nep- alensis, Schima wallichii, Castonopsis indica, Pinus roxburghii, Quercus spp., Rhododendron spp., etc. The Chandragiri Hills contains natural and planted forests and is managed as a community forest land.

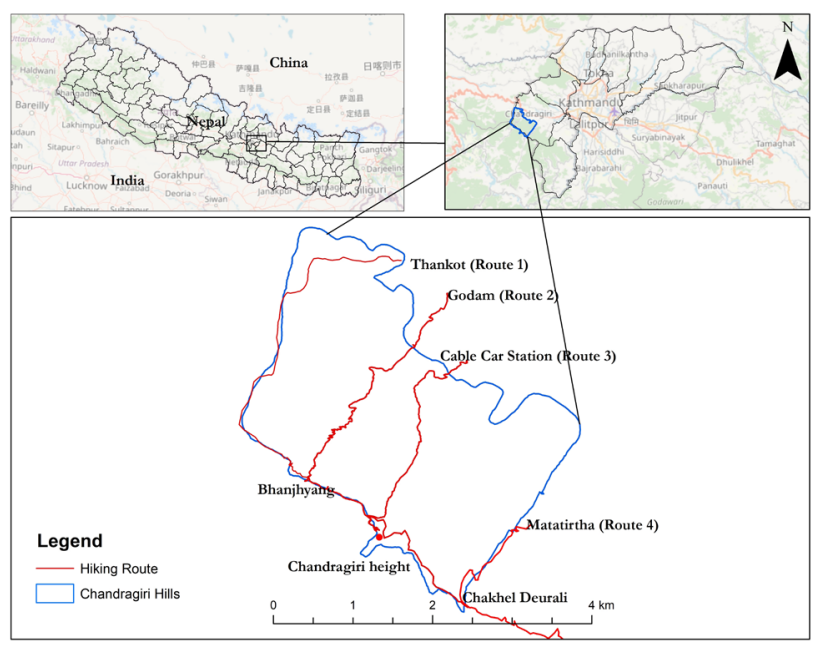

Figure 1: Boundary of Chandragiri Hills, Kathmandu with potential hiking routes.

\subsection{Study design}

We used multiple methods to detect wildlife species including direct observation, remote cameras, live traps, and species' sign observations. Surveys were conducted for 20 days in July 2015 during the monsoon season, which constrained our efforts to available trails $(0.5-4 \mathrm{~km}$ long) due to hazardous conditions off-trail by monsoon. We used direct observations and evidence of sign (e.g., tracks, scat, burrows) to identify mammal species along trails. We attached 10 cameras to trees along trails at locations considered likely to detect nocturnal species such as near animal trails. Cameras were typically positioned 40-50 $\mathrm{cm}$ above ground and operated from 18:00 to 7:00 am morning for 20 days, removing cameras daily to avoid theft. We surveyed birds along these same trails using line transect method (Bibby et al. 2000; Urfi et al. 2005; Siegel 2009) each morning from 6:30 to $12: 00$ noon, recording all species observed or heard. In addition, we also observed butterfly and herpetofauna along trails, open places and rivulets. We used field guides for mammals (Baral and Shah 2008), birds (Grimmett et al. 2000), butterflies (Smith 1994; Khanal and Smith 1997), and herpetofauna (Shah and Tiwari 2004) for species identification. We took photographs of all unidentified sign and species and consulted with experts for identification. Additionally, we also placed 40 live traps (Sherman/tube/ local/pitfall) for small mammals systematically bait- 
ed with balls of oatmeal, biscuit, carrot etc. in March 2019 for 25 days. We checked traps each morning and evening and released animals' onsite immediately after identification. Besides, we also consulted some key informants and made several opportunistic visits to survey butterflies, herpetofuana, birds (also reviewed ebird list) and mammals till May 2019.

We considered images from remote cameras taken $>30 \mathrm{~min}$ apart as independent events (see O'Brien et al. 2003; Jenks et al. 2011; Katuwal and Dahal 2013) and plotted detections time for each species. We compiled the list of species detected along with their conservation and trade status using the International Union for Conservation of Nature (IUCN) Red List of Threatened Species and the Convention on International Trade in Endangered Species of Wild Fauna and Flora (CITES) database, respectively.

\section{RESULTS \\ 2.1 Wildlife of Chandragiri Hills}

We recorded 30 mammal species (three species identified at genus level only) of 16 families (Appendix 1). We detected three globally threatened species (Chinese Pangolin Manis pentadactyla, Leopard Panthera pardus, and Himalayan Black Bear Ursus thibetanus), six nationally threatened species (Leopard Cat Prionailurus bengalensis, Leopard, Chinese Pangolin, Barking Deer Muntiacus vaginalis, Himalayan Black Bear and Assam Macaque $\mathrm{Ma}$ caca assamensis), and 10 were CITES listed species (Appendix 1 and 2). Through camera trapping, we confirmed the first occurrence of Chinese Pangolin in the Chandragiri Hills (Appendix 2). Our results indicated that most mammals were active during dawn and dusk (Figure 2). Large Indian Civet (Viverra zibetha) was recorded most frequently (48 detections) while Yellow-throated Marten (Martes flavigula) was detected only once. Among bats, we identified only the Woolly Horseshoe Bat (Rhinolophus luctus) and Greater Short-nosed Fruit Bat (Cynopterus sphinx).

We recorded 199 bird species from 47 families (Appendix 3). Most birds were resident (159 species) while some were winter (23 species) and summer (17 species) visitors. Among these bird species, we identified two globally threatened bird species (Steppe Eagle Aquila nipalensis and Red-headed Vulture Sarcogyps calvus), seven nationally threatened species (Common Barn-owl Tyto alba, Brown Wood-owl Strix leptogrammica, Steppe Eagle, Red-headed Vulture, Himalayan Griffon Gyps himalayensis, Plain-

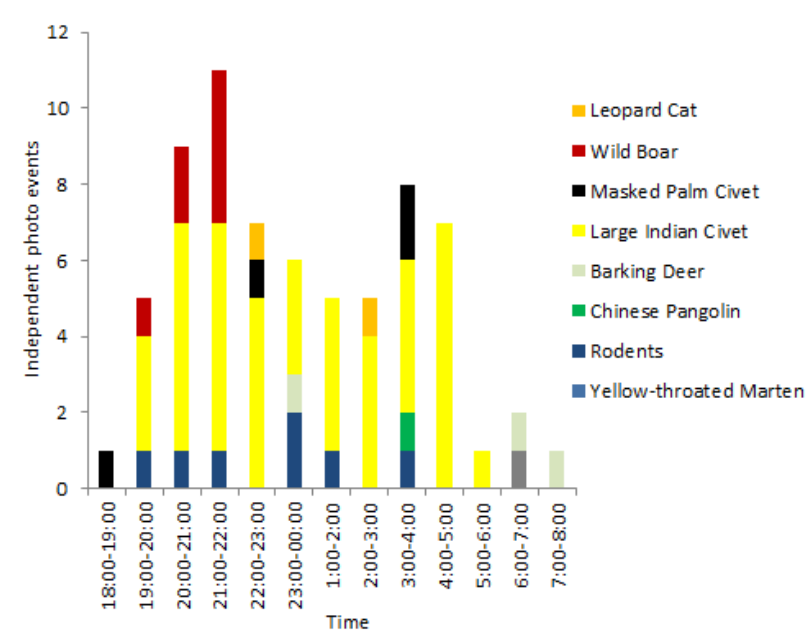

Figure 2: Frequency of mammals in camera traps at Chandragiri Hills in July 2015.

crowned Jay Garrulus bispecularis, and Gold-naped Finch Pyrrhoplectes epauletta), one was endemic species (Spiny Babbler Acanthoptila nipalensis), and 27 were CITES-listed species (Appendix 2 and 3).

We recorded 34 herpetofauna (10 amphibian species from five families, 24 reptile species from six families) (Appendix 2 and 4). The King Cobra (Ophiophagus hannah) was the only globally and nationally threatened (Vulnerable) species among the detected species in the Chandragiri Hills. We recorded 77 butterfly species from nine families (Appendix 2 and 5). The Golden Birdwing (Troides aeacus) was a CITES-listed species and the Common Siren (Diagora persimilis) was a nationally threatened species.

\subsection{Identifying potential hiking routes}

We identified four hiking routes in the Chandragiri Hills (see Figure 1):

Route 1) Thankot-Bhanjyang-Chandrigiri Hills: Visitors can start from Laglage Community Forest located in Thankot around $1300 \mathrm{~m}$ of elevation at the base of Kathmandu Valley. It is a well-managed hiking route for one hour and small trail afterward where visitors have opportunity to observe the Critically Endangered Chinese Pangolin and their burrows, other mammals like Wild Boar (Sus scrofa), Barking Deer (Muntiacus vaginalis) along with the signs of felid species like Leopard, forest birds and soaring raptors, butterflies, and herpetofauna along the trail. In addition, visitors can enjoy the scenery of Kathmandu valley along the eastern side and 
beautiful mountain landscape on the western side at an elevation of $2260 \mathrm{~m}$ in the Bhanjyang area within 3 hours walk from the starting point. After a 30-45 min walk from Bhanjyang, visitors can reach the Chandragiri peak $(2540 \mathrm{~m})$. From the top of the Chandragiri Hills, visitors can enjoy views of the Kathmandu Valley and panoramic view of the Himalayan Range from Mt. Annapurna I (8091 m) to Mt. Everest $(8848 \mathrm{~m})$ in clear days.

Route 2) Godam-Bhanjyang-Chandgiri Hills: Visitors can drive from Godam (Thankot area) to Bhanjyang to the top of Chandragiri, or can walk which takes 3-4 hours. It is one of the ancient routes that connect the Kathmandu with Terai region of Nepal. The road also goes to the Chitlang village from Bhanjyang which is a famous for homestays. Due to open space, this area is more suitable for observing birds, butterflies, primates, squirrels, and mammal signs (e.g., leopard, civet).

Route 3) Chandragiri cable car station-Chandragiri Hills: This is also the historic and most difficult hiking trail used by local people to reach the Bhaleshwor Mahadev temple at top of Chandragiri. The route starts from cable car station passing through dense forest and is around 2-3 hours hike to the top of Chandragiri. There is a higher chance of observing Chinese Pangolin and its burrows, civets and Barking Deer, along with many forest birds, butterflies and herpetofauna. Visitors can also use a cable car and see the scenic beauty of the Himalayan Range.

Route 4) Matatirtha-Chandragiri Hills: There is a drivable road till Chakhel Deurali and then hiking trail to the Chandragiri top. However, the visitors can directly use the hiking trail to reach the Chandragiri within 3-4 hours from Matatirtha. This hiking route provides excellent views of the Kathmandu Valley and Himalayan range. This area is the best for bird watching and observing different butterflies, herpetofauna, and mammals.

\section{Discussion}

This study outlined the relevance of Chandragiri Hills for the conservation of different faunal groups. Though presently it is not part of any protected area, it holds a very rich faunal diversity, which may be considered for both global and national importance.
The wildlife inventory and the potential tourist travel routes identified from this study can be served as a baseline data for developing ecotourism planning in Chandragiri Hills.

The observed species diversity in the Chandragiri Hills seems similar to that found in the nearest protected area, Shivapuri-Nagarjun National Park in mid-hills of Kathmandu (DNPWC 2020). For mammal species, most are widely distributed in Nepal except the Chinese Pangolin, which occurs predominantly from eastern to central Nepal (Sharma et al. 2020a). The local communities of Chandragiri areas are willing to protect threatened species like Chinese Pangolin because these communities have more knowledge on the importance of the species (Sharma et al. 2020b). As Leopards appear abundant in this area, human-leopard conflict is frequent (see the recent killing of the Leopard https://english.khabarhub. com/2020/07/94225/). It is also not surprising that many local people have experienced injuries, livestock and pets depredations from leopard. For example, people put spiked collars on their dogs to mitigate attacks from Leopard. Interestingly, the frequently detected Large Indian Civet and Yellow-throated Marten in Chandrgiri Hills may provide good opportunities for wildlife observers. These species are hardly recorded in the Kathmandu Valley probably due to their often nocturnal and crepuscular behavior (Hunter 2011; Appel et al. 2013) or limited studies of their occurrence. Records of both summer and winter birds suggest the Chandragiri Hills could be a potential site for bird watchers throughout the year. The Chandragiri Hills could also serve as an appropriate site for watching bird migrations (especially Steppe Eagles and other raptors) during winter season in the Kathmandu Valley (V. Thapa and A.V. Rissen personal communications), similar to Thoolakharka in Pokhara, Nepal (Subedi and Gurung, 2018). Due to the presence of fewer water sources in the study area, amphibian diversity and distribution was limited. However, the King Cobra, most often recorded from the low lands in Nepal, is now widely reported from the mid-hills region (Thapa et al. 2019), probably due to more studies. Diversity of butterflies also suggests that the Chandragiri Hills provide suitable habitat for these species. Although anthropogenic land-use change and ongoing climate change are impacting the occurrence, distribution and diversity of many herpetofauna and butterflies (Lütolf et al. 2009; Wanger et al. 2010; Acharya and Chettri 2012), IUCN has not 
assessed the conservation status of most of these species. Therefore, we suggest that regular monitoring of habitat, threatened species found in this area, and reducing all kinds of threats (for example, hunting and poaching of the species as we recorded several snares used to capture pheasants and observed children collecting the pheasant eggs and young, habitat loss and fragmentation, and unplanned construction activities) and associated conflicts should be a priority for community forest members and local government to conserving their biodiversity.

Although charismatic species are often the main attractions for ecotourism, tourists are showing increasing interest toward readily-accessible landscapes with greater diversity of plants, birds, herpetofuana, and butterflies, as well as rare, less easily-observed, or less high-profile mammal species (Loubser et al. 2001; Lindsay et al. 2007; Kurnianto et al. 2016; Hausmann 2016). As Chandragiri Hills is a largely intact system with unique landscapes and biodiversity ranging from sub-tropical to the temperate, it has potential for wildlife-based ecotourism. Local communities can develop lodging for visitors interested to explore this area. In addition, local/regional government should take the responsibility for its regulation and promotion and simultaneously precautions should be taken to mitigate potential negative impacts of tourism on the vegetation, watershed, and wildlife, especially threatened species. A code of conduct should be developed for tourists against the possible impacts on wild animals thorough direct mortality (e.g., vehicle collision), providing food to attract species, degrading crucial habitats, introducing of exotic species, and transmission of infectious diseases (Shannon et al. 2017).

\section{Conclusions}

The Chandragiri Hills near to Kathmandu is one of the potential areas for wildlife observation of national to global significance, as well as providing scenic Himalayan views for Nepalese and foreigners or people who have short stay at Kathmandu. The extent of open areas in Kathmandu is declining (Ishtiaque et al. 2017); therefore the Chandragiri Hills can provide unique opportunities to observe wildlife near the capital city. We recommend local government consider promoting through national and international media of this area, as well as additional actions to promote the conservation of nationally and globally threatened species and their habitats.

\section{ACKNOWLeDGeMents}

We thank the Department of Forests and Soil Conservation of Nepal for providing permission. This study was supported by HIMAWANTI-Nepal, Small Mammals Conservation and Research Foundation, and self-funding by co-authors. We thank Bird Conservation Nepal and Friends of Bird for conducting bird watching programs in the Chandragiri Hills and to all the people from the community forests for their support and suggestions during fieldwork. Additionally, we thank Vimal Thapa, Arend van Rissen, Hathan Chaudhary, Omkar Bhatt, Aditya Pal and Yam Bahadur Katuwal for updating some of the species and providing valuable suggestions, Jerrold L. Belant for revising the English and two anonymous reviewers for providing constructive comments on the manuscripts.

\section{CORresponding AUthor}

hembahadur@xtbg.ac.cn

\section{REFERENCES}

Acharya, B.K., and Chettri, B. (2012) Effect of climate change on Birds, Herpetofauna and Butterflies. In Arrawatia, M.L. and Tambe, S. (Eds.) Sikkim Himalaya: a preliminary investigation. Climate Change in Sikkim Patterns, Impacts and Initiatives, Information and Public Relations Department, Government of Sikkim, Gangtok.

Appel, A., Werhahn, G., Acharya, R., Ghimirey, Y., and Adhikary, B. (2013) Small carnivores in the Annapurna Conservation Area, Nepal. Vertebrate Zoology, 63, 11-121.

Baral, H.S. and Inskipp, C. (2005) Important Bird Areas in Nepal: Key sites for conservation. Bird Conservation Nepal and Birdlife International, Kathmandu and Cambridge.

Baral, H.S., and Shah, K.B. (2008) Wild mammals of Nepal. Himalayan Nature, Kathmandu.

Baral, N., Stern, M.J., and Hammett, A.L. (2012) Developing a scale for evaluating ecotourism by visitors: A study in the Annapurna conservation area, Nepal. Journal of Sustainable Tourism, 20, 975-989.

Bibby, C.J., Burgess, N.D., Hill, D.A., and Mustoe, S. (2000). Bird Census Techniques Second Edition. Great Britain: Academic Press.

Bookbinder, M.P., Dinerstein, E., Rijal, A., Cauley, H., and Rajouria, A. (1998) Ecotourism's support 
of biological conservation. Conservation Biology, 12, 1399-1404.

Cong, L., Newsome, D., Wu, B., and Morrison, A.M. (2014) Wildlife tourism in China: A review of the Chinese research literature. Current Issues in Tourism, 20, 1116-1139.

Donohoe, H.M. and Needham, R.D. (2006) Ecotourism: the evolving contemporary definition. Journal of Ecotourism, 5, 192-210.

DNPWC. (2018) Protected Areas of Nepal (Nepali version). Department of National Parks and Wildlife Conservation, Kathmandu, Nepal.

DNPWC. (2020) Shivapuri-Nagarjun National Park. http://www.dnpwc.gov.np/en/conservation-area-detail/70/.

Grimmett, R., Inskipp, C., and Inskipp, T. (2000) Birds of Nepal. Helm Field Guide, Prakash Books, New Delhi.

Hausmann, A., Slotow, R., Fraser, I., and Di Minin, E. (2016) Ecotourism marketing alternative to charismatic megafauna can also support biodiversity conservation. Animal Conservation, 20, 91-100.

Higginbottom, K. and Tribe, A. (2004) Contributions of wildlife tourism to conservation. In Higginbottom, K. (Eds.) Wildlife tourism - impacts, management and planning, Common Ground Publishing Ground Pty, Ltd, Australia.

Hunter, L. (2011) Carnivores of the world. Princeton University Press.

Inskipp, C., Baral, H.S., Phuyal, S., Bhatt, T.R., Katiwada, M., Inskipp, T., et al., (2016) The state of Nepal's bird: the national red list series. U.K: Zoological Society of London.

Ishtiaque, A., Shrestha, M., and Chhetri, N. (2017) Rapid urban growth in the Kathmandu Valley, Nepal: Monitoring land use land cover dynamics of a Himalayan city with Landsat imageries. Environments, 4, 72. https://doi.org/10.3390/environments4040072

Jenks, K.E., Chanteap, P., Damrongchainarong, K., Cutter, P., Redford, T., Lynam, A.J., et al., (2011) Using relative abundance indices from camera trapping to test wildlife conservation hypotheses - an example from KhaoYai National Park Thailand. Tropical Conservation Science, 4, 113-131.

Jnawali, S.R., Baral, H.S., Lee, S., Subedi, N., Acharya, K.P., Upadhyay, G.P., et al., (2011) The status of Nepal's mammals: the national red list se- ries, Department of National Parks and Wildlife Conservation, Kathmandu, Nepal.

Katuwal, H. B. and Dahal, S. (2013) Golden Jackals in human dominated landscape of the Manaslu conservation Area, Nepal. Vertebrate Zoology, 63, 315-319.

Katuwal, H.B., Sharma, H.P., Shaner, P.J.L., Gurung, R., Thapa, V., Magar, T.G., et al., (2018) Updating spatial information of 27 mammal species in Nepal. Journal of Animal and Plant Sciences, 28, 1735-1745.

KC, A., Rijal, K., and Sapkota, R. P. (2015) Role of ecotourism in environmental conservation and socioeconomic development in Annapurna conservation area, Nepal. International Journal of Sustainable Development of World, 22, 251-258.

Khanal, B., and Smith, C. (1997) Butterflies of Kathmandu Valley, Tec Press Books, Bangkok, Thailand.

Kurnianto, A.S., Wafa, I.Y., Alifianto, F., and Kurniawan, N. (2016) The potential of butterflies in tourism diversification product: Case study at Coban Rais waterfall, Batu, East Java. Journal of Indonesian Tourism and Development Studies, 2016, 4, 115-122.

Larm, M., Elmhagen, B., Granquist, S.M., Brundin, E., and Angerbjörn, A. (2018) The role of wildlife tourism in conservation of endangered species: Implications of safari tourism for conservation of the Arctic fox in Sweden. Human Dimension of Wildlife, 23, 257-272.

Lindsey, P.A., Alexander, R., Mills, M.G.L., Romañach, S., and Woodroffe, R. (2007) Wildlife viewing preferences of visitors to protected areas in South Africa: Implications for the role of ecotourism in conservation. Journal of Ecotourism, 6, 19-33.

Loubser, G.J.J., Mouton, P. le F.N., and Nel, J.A.J. (2001) The ecotourism potential of herpetofauna in the Namaqua National Park, South Africa. South African Journal of Wildlife Research, 31, 13-23.

Lütolf, M., Guisan, A., and Kienast, F. (2009) History matters: Relating land-use change to butterfly species occurrence. Environment Management, 43, 436-446.

O’Brien, T.G., Kinnaird, M.F., and Wibisono, H.T. (2003) Crouching tigers, hidden prey: Sumatran tiger and prey populations in a tropical forest landscape. Animal Conservation, 6, 131-139. 
Shah, K.B., and Tiwari, S. (2004) Herpetofauna of Nepal: A Conservation Companion - Kathmandu. IUCN Nepal, Kathmandu, Nepal.

Shannon, G., Larson, C.L., Reed, S.E., Crooks, K.R., and Angeloni, L.M. (2017) Ecological Consequences of Ecotourism for Wildlife Populations and Communities. In: Blumstein, D., Geffroy, B., Samia, D., Bessa, E. (Eds.) Ecotourism's Promise and Peril. Springer, Cham.

Sharma, H.P., Rimal, B., Zhang, M., Sharma, S., Poudyal, L.P., Maharjan, S., et al., (2020a) Potential distribution of the Critically Endangered Chinese Pangolin (Manis pentadactyla) in different land covers of Nepal: Implications for conservation. Sustainability, 12, 1282. doi:10.3390/ su12031282

Sharma, S., Sharma, H.P., Katuwal, H.B. and Belant, J.L. (2020b) Knowledge of the Critically Endangered Chinese pangolin (Manis pentadactyla) by local people in Sindhupalchok, Nepal. Global Ecology and Conservation, 23, e01052.

Siegel, R.B. (2009). Methods for monitoring land birds: a review commissioned by Seattle City Lights Wildlife Research Advisory Committee (2000). Natural Resource Report NPS/NCCN/
NRR - 2009/074. National Park Service, Fort Collins, Colorado.

Smith, C. (1994) Butterflies of Nepal, Craftsman Press, Bangkok.

Subdedi, T. and Gurung, S. (2018) Raptor Migration Summary Thoolakharka Nepal - Autumn 2018. Report submitted to Nepal Raptor Conservation Program, Himalayan Nature and Nepal Ornithological Union, Nepal.

Thapa, K.B., Rana, N., and Shah, K.B. (2019) Distribution of King Cobra in Nepal. Himalayan Naturalist, 2, 26-33.

Thomas, J.W. (1982) Needs For and Approaches To Wildlife Habitat Assessment, USDA Forest Service / UNL Faculty Publications. http://digitalcommons.unl.edu/usdafsfacpub/81

Urfi, A.J., Sen, M., Kalam, A., and Meganathan, T. (2005). Counting birds in India: Methodologies and trends. Current Science, 89, 1997-2003.

Wanger, T.C., Iskandar, D.T., Motzke, I., Brook, B.W., Sodhi, N.S., Clough, Y., et al., (2010) Effects of land-use change on community composition of tropical amphibians and reptiles in Sulawesi, Indonesia. Conservation Biology, 24, 795-802. 
Appendix 1: Mammals recorded in Chandragiri Hills where DD is Data Deficient, LC is Least Concern, NT is Near Threatened, VU is Vulnerable, CR is Critically Endangered.

\begin{tabular}{|c|c|c|c|c|c|c|}
\hline \multirow{2}{*}{ S. N. } & \multirow{2}{*}{$\begin{array}{l}\text { Order/Family/Common } \\
\text { Name }\end{array}$} & \multirow{2}{*}{ Scientific Name } & \multirow{2}{*}{$\begin{array}{l}\text { Sighting } \\
\text { Method }\end{array}$} & \multicolumn{2}{|c|}{ Conservation Status } & \multirow{2}{*}{$\begin{array}{l}\text { CITE } \\
\text { S }\end{array}$} \\
\hline & & & & National & IUCN & \\
\hline \multicolumn{7}{|c|}{ Carnivora } \\
\hline & Felidae & & & & & \\
\hline 1 & Jungle Cat & Felis chaus & Direct & $\mathrm{LC}$ & $\mathrm{LC}$ & II \\
\hline 2 & Leopard & Panthera pardus & Sign & VU & VU & $\mathrm{I}$ \\
\hline \multirow[t]{2}{*}{3} & Leopard Cat & $\begin{array}{l}\text { Prionailurus } \\
\text { bengalensis }\end{array}$ & Camera trap & VU & $\mathrm{LC}$ & II \\
\hline & Mustelidae & & & & & \\
\hline \multirow[t]{2}{*}{4} & Yellow-throated Marten & Martes flavigula & $\begin{array}{l}\text { Direct, } \\
\text { Camera trap }\end{array}$ & $\mathrm{LC}$ & LC & III \\
\hline & Ursidae & & & & & \\
\hline \multirow[t]{2}{*}{6} & Asiatic Black Bear & Ursus thibetanus & $\begin{array}{l}\text { Key } \\
\text { informant }\end{array}$ & EN & VU & $\mathrm{I}$ \\
\hline & Viverridae & & & & & \\
\hline 7 & Large Indian Civet & Viverra zibetha & $\begin{array}{l}\text { Camera trap, } \\
\text { Sign }\end{array}$ & NT & NT & III \\
\hline \multirow[t]{2}{*}{5} & Masked Palm Civet & Paguma larvata & $\begin{array}{l}\text { Direct, } \\
\text { Camera trap }\end{array}$ & $\mathrm{LC}$ & $\mathrm{LC}$ & \\
\hline & Canidae & & & & & \\
\hline 8 & Golden Jackal & Canis aureus & Direct & LC & $\mathrm{LC}$ & III \\
\hline \multicolumn{7}{|c|}{ Artiodactyla } \\
\hline \multirow{3}{*}{9} & Cervidae & & & & & \\
\hline & Barking Deer & Muntiacus vaginalis & $\begin{array}{l}\text { Direct, } \\
\text { Camera trap, } \\
\text { Sign }\end{array}$ & VU & $\mathrm{LC}$ & \\
\hline & Suidae & & & & & \\
\hline 10 & Wild Boar & Sus scrofa & $\begin{array}{l}\text { Direct, } \\
\text { Camera trap, } \\
\text { Sign }\end{array}$ & $\mathrm{LC}$ & $\mathrm{LC}$ & \\
\hline \multicolumn{7}{|c|}{ Chiroptera } \\
\hline & Rhinolophidae & & & & & \\
\hline \multirow[t]{2}{*}{11} & Woolly Horseshoe Bat & Rhinolophus luctus & Direct & $\mathrm{LC}$ & $\mathrm{LC}$ & \\
\hline & Pteropodidae & & & & & \\
\hline \multirow[t]{2}{*}{12} & Greater Shortnosed Fruit Bat & Cynopterus sphinx & Direct & $\mathrm{LC}$ & $\mathrm{LC}$ & \\
\hline & Vespertilionidae & & & & & \\
\hline 13 & Pipistrellus Bat & Pipistrelle spp. & Direct & & & \\
\hline \multicolumn{7}{|c|}{ Soricomorpha } \\
\hline & Soricidae & & & & & \\
\hline 14 & Asian House Shrew & Suncus murinus & $\begin{array}{l}\text { Direct, Live } \\
\text { trap }\end{array}$ & $\mathrm{LC}$ & $\mathrm{LC}$ & \\
\hline 15 & Himalayan Shrew & Soriculus nigrescens & Live trap & $\mathrm{LC}$ & LC & \\
\hline \multicolumn{7}{|c|}{ Pholidota } \\
\hline & Manidae & & & & & \\
\hline 16 & Chinese Pangolin & Manis pentadactyla & $\begin{array}{l}\text { Camera trap, } \\
\text { Sign }\end{array}$ & EN & $\mathrm{CR}$ & $\mathrm{I}$ \\
\hline
\end{tabular}




\begin{tabular}{|c|c|c|c|c|c|c|}
\hline \multicolumn{7}{|c|}{ Primates } \\
\hline & Cercopithecidae & & & & & \\
\hline 17 & Rhesus Macaque & Macaca mulatta & Direct & $\mathrm{LC}$ & $\mathrm{LC}$ & II \\
\hline 18 & Assam Macaque & Macaca assamensis & Direct & VU & NT & II \\
\hline \multicolumn{7}{|c|}{ Rodentia } \\
\hline & Muridae & & & & & \\
\hline 19 & House Rat & Rattus rattus & $\begin{array}{l}\text { Direct, Live } \\
\text { trap }\end{array}$ & $\mathrm{LC}$ & $\mathrm{LC}$ & \\
\hline 20 & Himalayan Rat & Rattus pyctoris & Live trap & $\mathrm{LC}$ & $\mathrm{LC}$ & \\
\hline 21 & Indo-Chinese Rat/ Sikkim Rat & $\begin{array}{l}\text { Rattus } \\
\text { andamanensis }\end{array}$ & Live trap & DD & $\mathrm{LC}$ & \\
\hline 22 & Fawn-colored Mouse & Mus cervicolor & Live trap & $\mathrm{LC}$ & $\mathrm{LC}$ & \\
\hline 23 & House Mouse & Mus musculus & Live trap & LC & $\mathrm{LC}$ & \\
\hline 24 & Soft-furred Rat & Millardia meltada & Live trap & LC & $\mathrm{LC}$ & \\
\hline 25 & Rat & Rattus sp. & Live trap & & & \\
\hline \multirow[t]{2}{*}{26} & Mouse & Mus sp. & Live trap & & & \\
\hline & Sciuridae & & & & & \\
\hline 27 & Irrawaddy Squirrel & $\begin{array}{l}\text { Callosciurus } \\
\text { pygerythrus }\end{array}$ & Direct & LC & $\mathrm{LC}$ & \\
\hline 28 & Particoloured Flying Squirrel & Hylopetes alboniger & Direct & $\mathrm{LC}$ & $\mathrm{LC}$ & \\
\hline \multirow[t]{2}{*}{29} & $\begin{array}{l}\text { Orange-bellied Himalayan } \\
\text { Squirrel }\end{array}$ & Dremomys lokriah & Direct & $\mathrm{LC}$ & $\mathrm{LC}$ & \\
\hline & Hystricidae & & & & & \\
\hline 30 & Indian Crested Procupine & Hystrix indica & Sign & DD & $\mathrm{LC}$ & \\
\hline
\end{tabular}


Appendix 2: Wildlife of Chandragiri Hills: a-e mammals (a-Chinese Pangolin, b-Wild Boar, c-Leopard Cat, d-Large Indian Civet, e-Masked Palm Civet), f-j birds (f-Golden-throated Barbet, g-Fire-breasted Flowerpecker, h-Gold-naped Finch, i-Steppe Eagle, j-Kalij Pheasant), k-o herpetofauna (k-King Cobra, 1-Darjeeling Worm Snake, m-Variegated Mountain Lizard, n- Marbled Toad, o-Myanmar Pelobatid Toad), p-t butterflies (p-Himalayan Jester, q- Grey Count, r-Colour Sergent, s-Large Silver Stripe, t-Indian Fritillary.

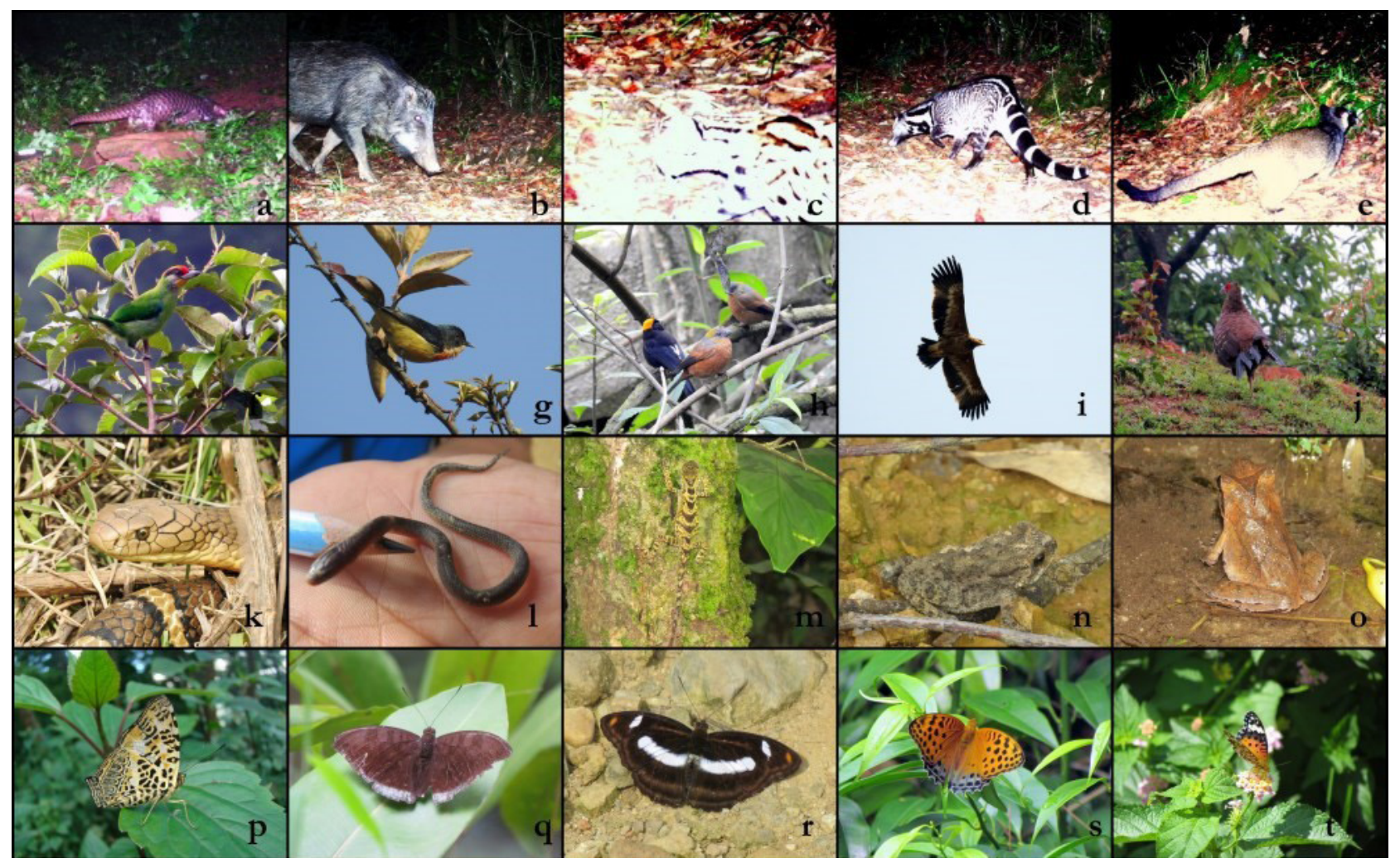


Appendix 3: Birds recorded in Chandragiri Hills where DD is Data Deficient, LC is Least Concern, NT is Near Threatened, VU is Vulnerable, EN is Endangered.

\begin{tabular}{|c|c|c|c|c|c|c|}
\hline \multirow{2}{*}{ S. N } & \multirow{2}{*}{$\begin{array}{l}\text { Order/Family/Commo } \\
\text { n Name }\end{array}$} & \multirow{2}{*}{ Scientific Name } & \multirow{2}{*}{$\begin{array}{l}\text { Migration } \\
\text { Status }\end{array}$} & \multicolumn{2}{|c|}{ Conservation Status } & \multirow{2}{*}{ CITES } \\
\hline & & & & National & IUCN & \\
\hline & Galliformes & & & & & \\
\hline & Phasianidae & & & & & \\
\hline 1 & Hill Partridge & $\begin{array}{l}\text { Arborophila } \\
\text { torqueola }\end{array}$ & Resident & $\mathrm{LC}$ & $\mathrm{LC}$ & \\
\hline \multirow[t]{3}{*}{2} & Kalij Pheasant & $\begin{array}{l}\text { Lophura } \\
\text { leucomelanos }\end{array}$ & Resident & $\mathrm{LC}$ & $\mathrm{LC}$ & III \\
\hline & Columbiformes & & & & & \\
\hline & Columbidae & & & & & \\
\hline 3 & Rock Dove & Columba livia & Resident & $\mathrm{LC}$ & $\mathrm{LC}$ & \\
\hline 4 & Speckled Woodpigeon & $\begin{array}{l}\text { Columba } \\
\text { hodgsonii }\end{array}$ & Resident & $\mathrm{LC}$ & $\mathrm{LC}$ & \\
\hline 5 & Oriental Turtle-dove & $\begin{array}{l}\text { Streptopelia } \\
\text { orientalis }\end{array}$ & Resident & $\mathrm{LC}$ & $\mathrm{LC}$ & \\
\hline 6 & Western Spotted Dove & $\begin{array}{l}\text { Spilopelia } \\
\text { suratensis }\end{array}$ & Resident & $\mathrm{LC}$ & $\mathrm{LC}$ & \\
\hline 7 & $\begin{array}{l}\text { Grey-capped Emerald } \\
\text { Dove }\end{array}$ & $\begin{array}{l}\text { Chalcophaps } \\
\text { indica }\end{array}$ & Resident & $\mathrm{LC}$ & $\mathrm{LC}$ & \\
\hline \multirow[t]{3}{*}{8} & $\begin{array}{l}\text { Wedge-tailed Green } \\
\text { Pigeon }\end{array}$ & $\begin{array}{l}\text { Treron } \\
\text { sphenurus }\end{array}$ & Resident & $\mathrm{LC}$ & $\mathrm{LC}$ & \\
\hline & Caprimulgiformes & & & & & \\
\hline & Apodidae & & & & & \\
\hline \multirow[t]{3}{*}{9} & House Swift & Apus nipalensis & Resident & $\mathrm{LC}$ & $\mathrm{LC}$ & \\
\hline & Cuculiformes & & & & & \\
\hline & Cuculidae & & & & & \\
\hline 10 & Greater Coucal & $\begin{array}{l}\text { Centropus } \\
\text { sinensis }\end{array}$ & $\begin{array}{l}\text { Resident/Su } \\
\text { mmer } \\
\text { migrant }\end{array}$ & $\mathrm{LC}$ & $\mathrm{LC}$ & \\
\hline 11 & Green-billed Malkoha & $\begin{array}{l}\text { Phaenicophaeus } \\
\text { tristis }\end{array}$ & Resident & $\mathrm{LC}$ & $\mathrm{LC}$ & \\
\hline 12 & Western Koel & $\begin{array}{l}\text { Eudynamys } \\
\text { scolopaceus }\end{array}$ & Resident & $\mathrm{LC}$ & $\mathrm{LC}$ & \\
\hline 13 & Common Cuckoo & Cuculus canorus & Resident & $\mathrm{LC}$ & $\mathrm{LC}$ & \\
\hline 14 & Oriental Cuckoo & $\begin{array}{l}\text { Cuculus } \\
\text { saturates }\end{array}$ & $\begin{array}{l}\text { Summer } \\
\text { migrant }\end{array}$ & $\mathrm{LC}$ & $\mathrm{LC}$ & \\
\hline 15 & Large Hawk-cuckoo & $\begin{array}{l}\text { Hierococcyx } \\
\text { sparverioides }\end{array}$ & Resident & $\mathrm{LC}$ & $\mathrm{LC}$ & \\
\hline 16 & Grey-bellied Cuckoo & $\begin{array}{l}\text { Cacomantis } \\
\text { passerines }\end{array}$ & $\begin{array}{l}\text { Summer } \\
\text { migrant }\end{array}$ & $\mathrm{LC}$ & $\mathrm{LC}$ & \\
\hline 17 & Lesser Cuckoo & $\begin{array}{l}\text { Cuculus } \\
\text { poliocephalus }\end{array}$ & $\begin{array}{l}\text { Summer } \\
\text { migrant }\end{array}$ & $\mathrm{LC}$ & $\mathrm{LC}$ & \\
\hline \multirow[t]{3}{*}{18} & $\begin{array}{l}\text { Fork-tailed Drongo- } \\
\text { cuckoo }\end{array}$ & $\begin{array}{l}\text { Surniculus } \\
\text { dicruroides }\end{array}$ & $\begin{array}{l}\text { Summer } \\
\text { migrant }\end{array}$ & $\mathrm{LC}$ & $\mathrm{LC}$ & \\
\hline & Pelecaniformes & & & & & \\
\hline & Ardeidae & & & & & \\
\hline 19 & Cattle Egret & Bubulcus ibis & Resident & $\mathrm{LC}$ & $\mathrm{LC}$ & \\
\hline 20 & Indian Pond-heron & Ardeola grayii & Resident & $\mathrm{LC}$ & $\mathrm{LC}$ & \\
\hline 21 & Little Egret & Egretta garzetta & Resident & $\mathrm{LC}$ & $\mathrm{LC}$ & \\
\hline
\end{tabular}


Hem Bahadur Katuwal et Al. - Wildlife Assessment ofthe Chandragiri Hills, Kathmandu

\begin{tabular}{|c|c|c|c|c|c|c|}
\hline & Strigiformes & & & & & \\
\hline & Tytonidae & & & & & \\
\hline \multirow[t]{2}{*}{22} & Common Barn-owl & Tyto alba & Resident & VU & $\mathrm{LC}$ & II \\
\hline & Strigidae & & & & & \\
\hline 23 & Spotted Owlet & Athene brama & Resident & $\mathrm{LC}$ & $\mathrm{LC}$ & II \\
\hline 24 & Mountain Scops-owl & $\begin{array}{l}\text { Otus } \\
\text { spilocephalus }\end{array}$ & Resident & $\mathrm{LC}$ & $\mathrm{LC}$ & II \\
\hline 25 & Collared Owlet & $\begin{array}{l}\text { Glaucidium } \\
\text { brodiei }\end{array}$ & Resident & $\mathrm{LC}$ & $\mathrm{LC}$ & II \\
\hline 26 & Brown Wood-owl & $\begin{array}{l}\text { Strix } \\
\text { leptogrammica }\end{array}$ & Resident & VU & $\mathrm{LC}$ & II \\
\hline 27 & Asian Barred Owlet & $\begin{array}{l}\text { Glaucidium } \\
\text { cuculoides }\end{array}$ & Resident & $\mathrm{LC}$ & $\mathrm{LC}$ & II \\
\hline \multirow[t]{3}{*}{28} & Rock Eagle-owl & $\begin{array}{l}\text { Bubo } \\
\text { bengalensis }\end{array}$ & Resident & VU & $\mathrm{LC}$ & \\
\hline & Accipitriformes & & & & & \\
\hline & Accipitridae & & & & & \\
\hline 29 & Crested Serpent-eagle & Spilornis cheela & Resident & $\mathrm{LC}$ & $\mathrm{LC}$ & II \\
\hline 30 & Black Kite & Milvus migrans & Resident & $\mathrm{LC}$ & $\mathrm{LC}$ & II \\
\hline 31 & Shikra & Accipiter badius & Resident & $\mathrm{LC}$ & $\mathrm{LC}$ & II \\
\hline 32 & Steppe Eagle & Aquila nipalensis & $\begin{array}{l}\text { Winter } \\
\text { migrant }\end{array}$ & VU & EN & II \\
\hline 33 & Northern Goshawk & Accipiter gentilis & Resident & $\mathrm{LC}$ & $\mathrm{LC}$ & II \\
\hline 34 & Mountain Hawk-eagle & $\begin{array}{l}\text { Nisaetus } \\
\text { nipalensis }\end{array}$ & Resident & $\mathrm{LC}$ & $\mathrm{LC}$ & II \\
\hline 35 & Black Eagle & $\begin{array}{l}\text { Ictinaetus } \\
\text { malaiensis }\end{array}$ & Resident & $\mathrm{LC}$ & $\mathrm{LC}$ & II \\
\hline 36 & Himalayan Buzzard & Buteo refectus & $\begin{array}{l}\text { Winter } \\
\text { migrant }\end{array}$ & $\mathrm{LC}$ & $\mathrm{LC}$ & II \\
\hline 37 & Long-legged Buzzard & Buteo rufinus & $\begin{array}{l}\text { Winter } \\
\text { migrant }\end{array}$ & $\mathrm{LC}$ & $\mathrm{LC}$ & II \\
\hline 38 & Red-headed Vulture & Sarcogyps calvus & Resident & EN & $\mathrm{CR}$ & II \\
\hline 39 & Himalayan Griffon & $\begin{array}{l}\text { Gyps } \\
\text { himalayensis }\end{array}$ & Resident & VU & NT & II \\
\hline 40 & $\begin{array}{l}\text { Oriental } \\
\text { buzzard }\end{array}$ & $\begin{array}{l}\text { Pernis } \\
\text { ptilorhynchus }\end{array}$ & Resident & $\mathrm{LC}$ & $\mathrm{LC}$ & II \\
\hline 41 & Bonelli's Eagle & Aquila fasciata & $\begin{array}{l}\text { Winter } \\
\text { migrant }\end{array}$ & $\mathrm{LC}$ & $\mathrm{LC}$ & II \\
\hline 42 & Booted Eagle & $\begin{array}{l}\text { Hieraaetus } \\
\text { pennatus }\end{array}$ & $\begin{array}{l}\text { Winter } \\
\text { migrant }\end{array}$ & $\mathrm{LC}$ & $\mathrm{LC}$ & II \\
\hline \multirow[t]{3}{*}{43} & Besra & $\begin{array}{l}\text { Accipiter } \\
\text { virgatus }\end{array}$ & Resident & $\mathrm{LC}$ & $\mathrm{LC}$ & II \\
\hline & Bucerotiformes & & & & & \\
\hline & Upupidae & & & & & \\
\hline \multirow[t]{3}{*}{44} & Common Hoopoe & Upupa epops & Resident & $\mathrm{LC}$ & $\mathrm{LC}$ & \\
\hline & Coraciiformes & & & & & \\
\hline & Alcedinidae & & & & & \\
\hline 45 & White-breasted & Halcyon & Resident & $\mathrm{LC}$ & $\mathrm{LC}$ & \\
\hline
\end{tabular}




\begin{tabular}{|c|c|c|c|c|c|c|}
\hline & Kingfisher & smyrnensis & & & & \\
\hline & Piciformes & & & & & \\
\hline & Megalaimidae & & & & & \\
\hline 46 & Great Barbet & $\begin{array}{l}\text { Psilopogon } \\
\text { virens }\end{array}$ & Resident & $\mathrm{LC}$ & $\mathrm{LC}$ & \\
\hline 47 & $\begin{array}{l}\text { Golden-throated } \\
\text { Barbet }\end{array}$ & $\begin{array}{l}\text { Psilopogon } \\
\text { franklinii }\end{array}$ & Resident & $\mathrm{LC}$ & $\mathrm{LC}$ & \\
\hline \multirow[t]{2}{*}{48} & Blue-throated Barbet & $\begin{array}{l}\text { Psilopogon } \\
\text { asiatica }\end{array}$ & Resident & $\mathrm{LC}$ & $\mathrm{LC}$ & \\
\hline & Picidae & & & & & \\
\hline 49 & $\begin{array}{l}\text { Scarlet-breasted } \\
\text { Woodpecker }\end{array}$ & $\begin{array}{l}\text { Dryobates } \\
\text { cathpharius }\end{array}$ & Resident & $\mathrm{LC}$ & $\mathrm{LC}$ & \\
\hline 50 & $\begin{array}{l}\text { Rufous-bellied } \\
\text { Woodpecker }\end{array}$ & $\begin{array}{l}\text { Dendrocopos } \\
\text { hyperythrus }\end{array}$ & Resident & $\mathrm{LC}$ & $\mathrm{LC}$ & \\
\hline 51 & $\begin{array}{l}\text { Darjeeling } \\
\text { Woodpecker }\end{array}$ & $\begin{array}{l}\text { Dendrocopos } \\
\text { darjellensis }\end{array}$ & Resident & $\mathrm{LC}$ & $\mathrm{LC}$ & \\
\hline 52 & Lesser Yellownape & $\begin{array}{l}\text { Picus } \\
\text { chlorolophus }\end{array}$ & Resident & $\mathrm{LC}$ & $\mathrm{LC}$ & \\
\hline 53 & Greater Yellownape & $\begin{array}{l}\text { Chrysophlegma } \\
\text { flavinucha }\end{array}$ & Resident & $\mathrm{LC}$ & $\mathrm{LC}$ & \\
\hline 54 & $\begin{array}{l}\text { Grey-capped } \\
\text { Woodpecker }\end{array}$ & $\begin{array}{l}\text { Picoides } \\
\text { canicapillus }\end{array}$ & Resident & $\mathrm{LC}$ & $\mathrm{LC}$ & \\
\hline \multirow[t]{3}{*}{55} & Speckled Piculet & $\begin{array}{l}\text { Picumnus } \\
\text { innominatus }\end{array}$ & Resident & $\mathrm{LC}$ & $\mathrm{LC}$ & \\
\hline & Cariamiformes & & & & & \\
\hline & Falconidae & & & & & \\
\hline 56 & Eurasian Hobby & Falco subbuteo & $\begin{array}{l}\text { Passage } \\
\text { migrant }\end{array}$ & $\mathrm{LC}$ & $\mathrm{LC}$ & II \\
\hline 57 & Common Kestrel & $\begin{array}{l}\text { Falco } \\
\text { tinnunculus }\end{array}$ & $\begin{array}{l}\text { Resident and } \\
\text { passage } \\
\text { migrant }\end{array}$ & $\mathrm{LC}$ & $\mathrm{LC}$ & II \\
\hline \multirow[t]{3}{*}{58} & Peregrine Falcon & Falco peregrinus & Resident & $\mathrm{LC}$ & $\mathrm{LC}$ & I \\
\hline & Psittaciformes & & & & & \\
\hline & Psittacidae & & & & & \\
\hline 59 & Alexandrine Parakeet & $\begin{array}{l}\text { Psittacula } \\
\text { eupatria }\end{array}$ & Resident & $\mathrm{LC}$ & NT & II \\
\hline 60 & Rose-ringed Parakeet & $\begin{array}{l}\text { Psittacula } \\
\text { krameri }\end{array}$ & Resident & $\mathrm{LC}$ & $\mathrm{LC}$ & \\
\hline \multirow[t]{3}{*}{61} & Slaty-headed Parakeet & $\begin{array}{l}\text { Psittacula } \\
\text { himalayana }\end{array}$ & Resident & $\mathrm{LC}$ & $\mathrm{LC}$ & II \\
\hline & Passeriformes & & & & & \\
\hline & Oriolidae & & & & & \\
\hline 62 & Maroon Oriole & Oriolus traillii & Resident & $\mathrm{LC}$ & $\mathrm{LC}$ & \\
\hline \multirow[t]{2}{*}{63} & Indian Golden Oriole & Oriolus kundoo & $\begin{array}{l}\text { Summer } \\
\text { migrant }\end{array}$ & $\mathrm{LC}$ & $\mathrm{LC}$ & \\
\hline & Vireonidae & & & & & \\
\hline 64 & White-bellied Erpornis & $\begin{array}{l}\text { Erpornis } \\
\text { zantholeuca }\end{array}$ & Resident & $\mathrm{LC}$ & $\mathrm{LC}$ & \\
\hline
\end{tabular}


Hem Bahadur Katuwal et Al. - Wildlife Assessment ofthe Chandragiri Hills, Kathmandu

\begin{tabular}{|c|c|c|c|c|c|}
\hline & Campephagidae & & & & \\
\hline 65 & Long-tailed Minivet & $\begin{array}{l}\text { Pericrocotus } \\
\text { ethologus }\end{array}$ & Resident & $\mathrm{LC}$ & $\mathrm{LC}$ \\
\hline 66 & Scarlet Minivet & $\begin{array}{l}\text { Pericrocotus } \\
\text { flammeus }\end{array}$ & Resident & $\mathrm{LC}$ & $\mathrm{LC}$ \\
\hline 67 & Indian Cuckooshrike & Coracina macei & Resident & $\mathrm{LC}$ & $\mathrm{LC}$ \\
\hline \multirow[t]{2}{*}{68} & $\begin{array}{l}\text { Black-winged } \\
\text { Cuckooshrike }\end{array}$ & $\begin{array}{l}\text { Lalage } \\
\text { melaschistos }\end{array}$ & Resident & $\mathrm{LC}$ & $\mathrm{LC}$ \\
\hline & Rhipiduridae & & & & \\
\hline \multirow[t]{2}{*}{69} & White-throated Fantail & $\begin{array}{l}\text { Rhipidura } \\
\text { albicollis }\end{array}$ & Resident & $\mathrm{LC}$ & $\mathrm{LC}$ \\
\hline & Dicruridae & & & & \\
\hline 70 & Black Drongo & $\begin{array}{l}\text { Dicrurus } \\
\text { macrocercus }\end{array}$ & Resident & $\mathrm{LC}$ & $\mathrm{LC}$ \\
\hline 71 & Ashy Drongo & $\begin{array}{l}\text { Dicrurus } \\
\text { leucophaeus }\end{array}$ & $\begin{array}{l}\text { Resident and } \\
\text { partial } \\
\text { migrant }\end{array}$ & $\mathrm{LC}$ & $\mathrm{LC}$ \\
\hline 72 & Hair-crested Drongo & $\begin{array}{l}\text { Dicrurus } \\
\text { hottentottus }\end{array}$ & Resident & $\mathrm{LC}$ & $\mathrm{LC}$ \\
\hline 73 & Bronzed Drongo & Dicrurus aeneus & Resident & $\mathrm{LC}$ & $\mathrm{LC}$ \\
\hline \multirow[t]{2}{*}{74} & $\begin{array}{l}\text { Lesser Racquet-tailed } \\
\text { Drongo }\end{array}$ & Dicrurus remifer & Resident & $\mathrm{LC}$ & $\mathrm{LC}$ \\
\hline & Laniidae & & & & \\
\hline 75 & Long-tailed Shrike & Lanius schach & Resident & $\mathrm{LC}$ & $\mathrm{LC}$ \\
\hline 76 & Grey-backed Shrike & $\begin{array}{l}\text { Lanius } \\
\text { tephronotus } \\
\end{array}$ & $\begin{array}{l}\text { Winter } \\
\text { migrant }\end{array}$ & $\mathrm{LC}$ & $\mathrm{LC}$ \\
\hline \multirow[t]{2}{*}{77} & Brown Shrike & Lanius cristatus & $\begin{array}{l}\text { Winter } \\
\text { migrant }\end{array}$ & $\mathrm{LC}$ & $\mathrm{LC}$ \\
\hline & Corvidae & & & & \\
\hline 78 & Rufous Treepie & $\begin{array}{l}\text { Dendrocitta } \\
\text { vagabunda }\end{array}$ & Resident & $\mathrm{LC}$ & $\mathrm{LC}$ \\
\hline 79 & Grey Treepie & $\begin{array}{l}\text { Dendrocitta } \\
\text { formosae }\end{array}$ & Resident & $\mathrm{LC}$ & $\mathrm{LC}$ \\
\hline 80 & Plain-crowned Jay & $\begin{array}{l}\text { Garrulus } \\
\text { bispecularis }\end{array}$ & Resident & EN & $\mathrm{LC}$ \\
\hline 81 & Black-headed Jay & $\begin{array}{l}\text { Garrulus } \\
\text { lanceolatus }\end{array}$ & $\begin{array}{l}\text { Winter } \\
\text { migrant }\end{array}$ & $\mathrm{LC}$ & $\mathrm{LC}$ \\
\hline 82 & House Crow & $\begin{array}{l}\text { Corvus } \\
\text { splendens }\end{array}$ & Resident & $\mathrm{LC}$ & $\mathrm{LC}$ \\
\hline 83 & Large-billed Crow & $\begin{array}{l}\text { Corvus } \\
\text { macrorhynchos }\end{array}$ & Resident & $\mathrm{LC}$ & $\mathrm{LC}$ \\
\hline 84 & $\begin{array}{ll}\text { Red-billed } & \text { Blue } \\
\text { Magpie } & \\
\end{array}$ & $\begin{array}{l}\text { Urocissa } \\
\text { erythroryncha }\end{array}$ & Resident & $\mathrm{LC}$ & $\mathrm{LC}$ \\
\hline \multirow[t]{2}{*}{85} & $\begin{array}{ll}\text { Common } & \text { Green } \\
\text { Magpie } & \\
\end{array}$ & Cissa chinensis & Resident & $\mathrm{LC}$ & $\mathrm{LC}$ \\
\hline & Stenostiridae & & & & \\
\hline 86 & $\begin{array}{l}\text { Yellow-bellied Fairy- } \\
\text { fantail }\end{array}$ & $\begin{array}{l}\text { Chelidorhynx } \\
\text { hypoxanthus }\end{array}$ & Resident & $\mathrm{LC}$ & $\mathrm{LC}$ \\
\hline \multirow[t]{2}{*}{87} & $\begin{array}{l}\text { Grey-headed Canary- } \\
\text { flycatcher }\end{array}$ & $\begin{array}{l}\text { Culicicapa } \\
\text { ceylonensis }\end{array}$ & $\begin{array}{l}\text { Partial } \\
\text { migrant }\end{array}$ & $\mathrm{LC}$ & $\mathrm{LC}$ \\
\hline & Paridae & & & & \\
\hline
\end{tabular}




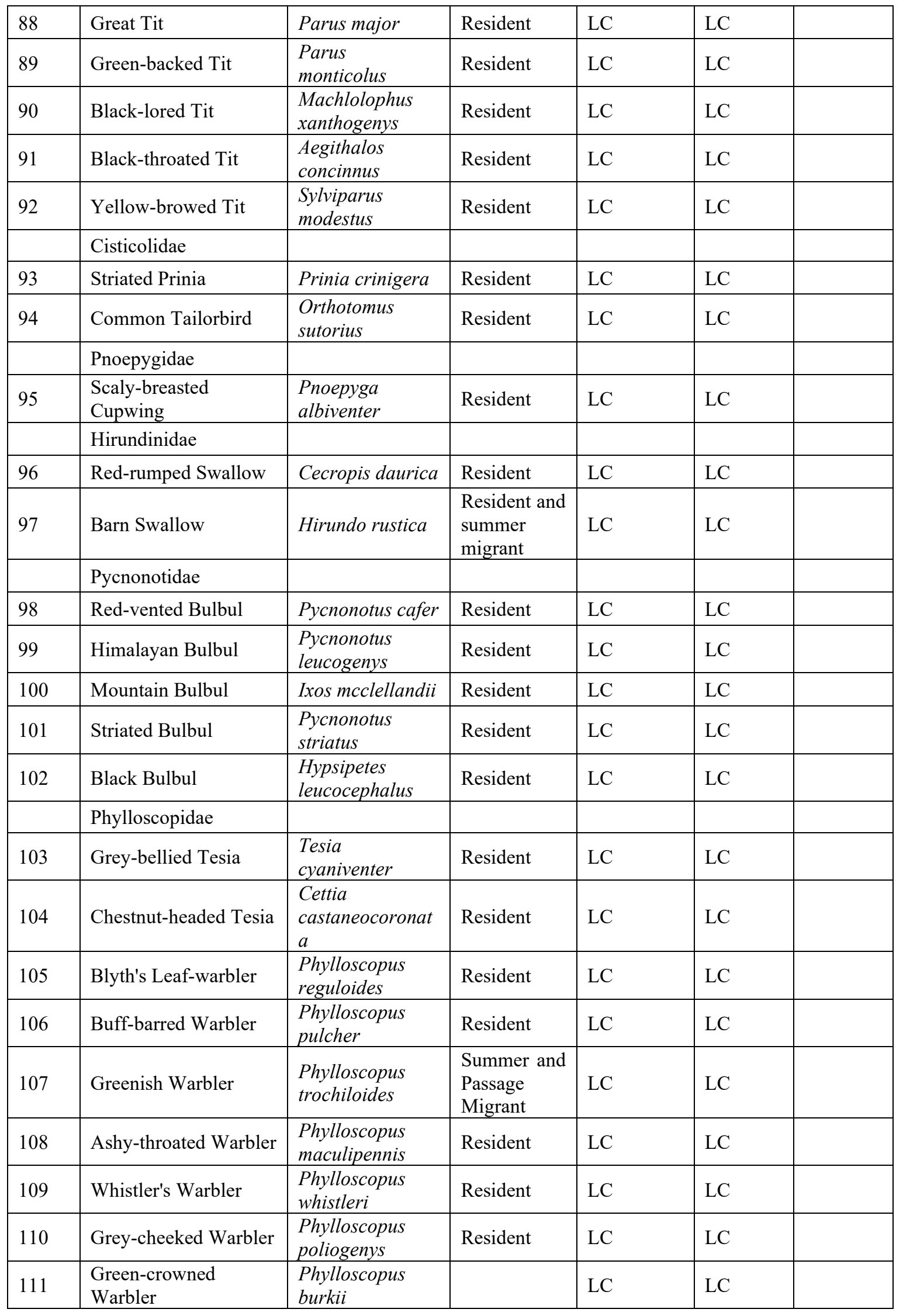




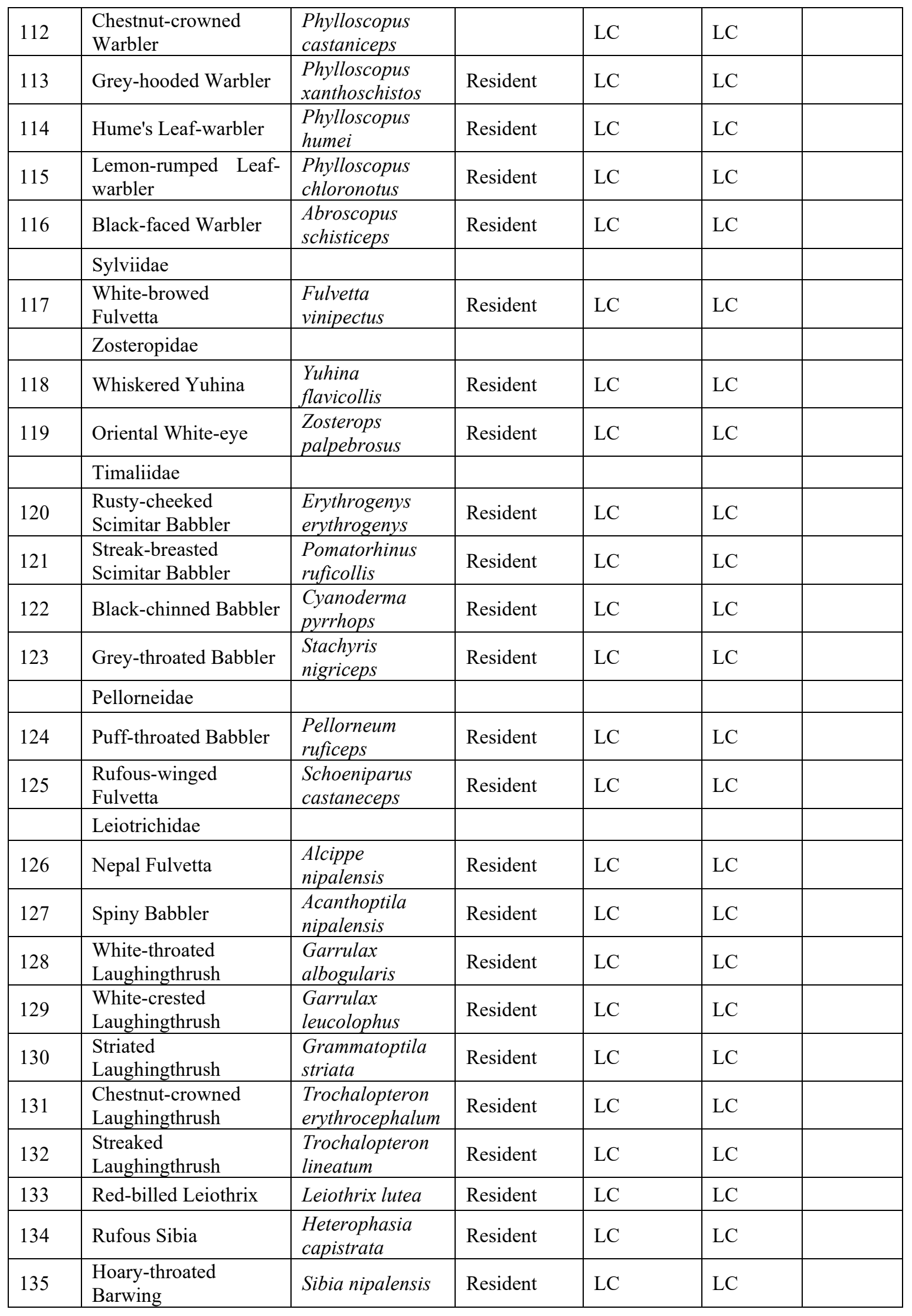




\begin{tabular}{|c|c|c|c|c|c|}
\hline 136 & Blue-winged Minla & $\begin{array}{l}\text { Siva } \\
\text { cyanouroptera }\end{array}$ & Resident & LC & LC \\
\hline & Certhiidae & & & & \\
\hline \multirow[t]{2}{*}{137} & $\begin{array}{l}\text { Rusty-flanked } \\
\text { Treecreeper }\end{array}$ & $\begin{array}{l}\text { Certhia } \\
\text { nipalensis }\end{array}$ & Reident & $\mathrm{LC}$ & LC \\
\hline & Sittidae & & & & \\
\hline 138 & $\begin{array}{l}\text { Chestnut-bellied } \\
\text { Nuthatch }\end{array}$ & $\begin{array}{l}\text { Sitta } \\
\text { cinnamoventris }\end{array}$ & Resident & $\mathrm{LC}$ & LC \\
\hline 139 & $\begin{array}{l}\text { Velvet-fronted } \\
\text { Nuthatch }\end{array}$ & Sitta frontalis & Resident & $\mathrm{LC}$ & $\mathrm{LC}$ \\
\hline \multirow[t]{2}{*}{140} & White-tailed Nuthatch & $\begin{array}{l}\text { Sitta } \\
\text { himalayensis }\end{array}$ & Resident & $\mathrm{LC}$ & $\mathrm{LC}$ \\
\hline & Sturnidae & & & & \\
\hline 141 & Common Myna & $\begin{array}{l}\text { Acridotheres } \\
\text { tristis }\end{array}$ & Resident & $\mathrm{LC}$ & $\mathrm{LC}$ \\
\hline 142 & Jungle Myna & $\begin{array}{l}\text { Acridotheres } \\
\text { fuscus }\end{array}$ & Resident & $\mathrm{LC}$ & $\mathrm{LC}$ \\
\hline 143 & $\begin{array}{l}\text { Chestnut-tailed } \\
\text { Starling }\end{array}$ & $\begin{array}{l}\text { Sturnia } \\
\text { malabarica }\end{array}$ & Resident & $\mathrm{LC}$ & $\mathrm{LC}$ \\
\hline \multirow[t]{2}{*}{144} & Brahminy Starling & $\begin{array}{l}\text { Sturnia } \\
\text { pagodarum }\end{array}$ & Resident & $\mathrm{LC}$ & $\mathrm{LC}$ \\
\hline & Turdidae & & & & \\
\hline 145 & Pied Thrush & Geokichla wardii & $\begin{array}{l}\text { Summer } \\
\text { migrant }\end{array}$ & $\mathrm{LC}$ & $\mathrm{LC}$ \\
\hline 146 & Scaly Thrush & Zoothera dauma & $\begin{array}{l}\text { Winter } \\
\text { migrant }\end{array}$ & $\mathrm{LC}$ & $\mathrm{LC}$ \\
\hline 147 & Tibetan Blackbird & Turdus maximus & Resident & $\mathrm{LC}$ & $\mathrm{LC}$ \\
\hline 148 & Black-throated Thrush & $\begin{array}{l}\text { Turdus } \\
\text { atrogularis }\end{array}$ & $\begin{array}{l}\text { Winter } \\
\text { migrant }\end{array}$ & $\mathrm{LC}$ & $\mathrm{LC}$ \\
\hline 149 & $\begin{array}{l}\text { Grey-winged } \\
\text { Blackbird }\end{array}$ & Turdus boulboul & Resident & $\mathrm{LC}$ & $\mathrm{LC}$ \\
\hline \multirow[t]{2}{*}{150} & $\begin{array}{l}\text { White-collared } \\
\text { Blackbird }\end{array}$ & $\begin{array}{l}\text { Turdus } \\
\text { albocinctus }\end{array}$ & Resident & $\mathrm{LC}$ & $\mathrm{LC}$ \\
\hline & Muscicapidae & & & & \\
\hline 151 & Oriental Magpie-robin & $\begin{array}{l}\text { Copsychus } \\
\text { saularis }\end{array}$ & Resident & $\mathrm{LC}$ & $\mathrm{LC}$ \\
\hline 152 & Dark-sided Flycatcher & $\begin{array}{l}\text { Muscicapa } \\
\text { sibirica }\end{array}$ & $\begin{array}{l}\text { Summer } \\
\text { migrant }\end{array}$ & $\mathrm{LC}$ & $\mathrm{LC}$ \\
\hline 153 & $\begin{array}{l}\text { Rufous-gorgeted } \\
\text { Flycatcher }\end{array}$ & $\begin{array}{l}\text { Ficedula } \\
\text { strophiata }\end{array}$ & Resident & LC & $\mathrm{LC}$ \\
\hline 154 & Verditer Flycatcher & $\begin{array}{l}\text { Eumyias } \\
\text { thalassinus }\end{array}$ & $\begin{array}{l}\text { Resident and } \\
\text { partial } \\
\text { migrant }\end{array}$ & $\mathrm{LC}$ & $\mathrm{LC}$ \\
\hline 155 & Slaty-blue Flycatcher & Ficedula tricolor & $\begin{array}{l}\text { Winter } \\
\text { migrant }\end{array}$ & $\mathrm{LC}$ & $\mathrm{LC}$ \\
\hline 156 & $\begin{array}{l}\text { Ultramarine } \\
\text { Flycatcher }\end{array}$ & $\begin{array}{l}\text { Ficedula } \\
\text { superciliaris }\end{array}$ & $\begin{array}{l}\text { Summer } \\
\text { migrant }\end{array}$ & $\mathrm{LC}$ & $\mathrm{LC}$ \\
\hline 157 & $\begin{array}{l}\text { Red-throated } \\
\text { Flycatcher }\end{array}$ & $\begin{array}{l}\text { Ficedula } \\
\text { albicilla }\end{array}$ & $\begin{array}{l}\text { Winter } \\
\text { migrant }\end{array}$ & $\mathrm{LC}$ & $\mathrm{LC}$ \\
\hline 158 & Blue Whistling-thrush & $\begin{array}{l}\text { Myophonus } \\
\text { caeruleus }\end{array}$ & Resident & $\mathrm{LC}$ & $\mathrm{LC}$ \\
\hline 159 & $\begin{array}{l}\text { Blue-capped Rock- } \\
\text { thrush }\end{array}$ & $\begin{array}{l}\text { Monticola } \\
\text { cinclorhyncha }\end{array}$ & $\begin{array}{l}\text { Summer } \\
\text { migrant }\end{array}$ & LC & LC \\
\hline
\end{tabular}


Hem Bahadur Katuwal et Al. - Wildlife Assessment ofthe Chandragiri Hills, Kathmandu

\begin{tabular}{|c|c|c|c|c|c|}
\hline 160 & $\begin{array}{l}\text { Chestnut-bellied } \\
\text { Rock-thrush }\end{array}$ & $\begin{array}{l}\text { Monticola } \\
\text { rufiventris }\end{array}$ & Resident & $\mathrm{LC}$ & $\mathrm{LC}$ \\
\hline 161 & Small Niltava & $\begin{array}{l}\text { Niltava } \\
\text { macgrigoriae }\end{array}$ & Resident & $\mathrm{LC}$ & $\mathrm{LC}$ \\
\hline 162 & Rufous-bellied Niltava & Niltava sundara & Resident & $\mathrm{LC}$ & $\mathrm{LC}$ \\
\hline 163 & Indian Blue Robin & $\begin{array}{l}\text { Larvivora } \\
\text { brunnea }\end{array}$ & Resident & $\mathrm{LC}$ & $\mathrm{LC}$ \\
\hline 164 & $\begin{array}{l}\text { White-tailed } \quad \text { Blue } \\
\text { Robin }\end{array}$ & $\begin{array}{l}\text { Myiomela } \\
\text { leucura }\end{array}$ & Resident & $\mathrm{LC}$ & $\mathrm{LC}$ \\
\hline 165 & Spotted Forktail & $\begin{array}{l}\text { Enicurus } \\
\text { maculatus }\end{array}$ & Resident & $\mathrm{LC}$ & $\mathrm{LC}$ \\
\hline 166 & Slaty-backed Forktail & $\begin{array}{l}\text { Enicurus } \\
\text { schistaceus }\end{array}$ & Resident & $\mathrm{LC}$ & $\mathrm{LC}$ \\
\hline 167 & Hodgson's Redstart & $\begin{array}{l}\text { Phoenicurus } \\
\text { hodgsoni }\end{array}$ & $\begin{array}{l}\text { Winter } \\
\text { migrant }\end{array}$ & $\mathrm{LC}$ & $\mathrm{LC}$ \\
\hline 168 & $\begin{array}{ll}\begin{array}{l}\text { Plumbeous } \\
\text { redstart }\end{array} & \text { Water- } \\
\end{array}$ & $\begin{array}{l}\text { Phoenicurus } \\
\text { fuliginosus }\end{array}$ & Resident & $\mathrm{LC}$ & $\mathrm{LC}$ \\
\hline 169 & $\begin{array}{l}\text { White-capped Water- } \\
\text { redstart }\end{array}$ & $\begin{array}{l}\text { Phoenicurus } \\
\text { leucocephalus }\end{array}$ & Resident & $\mathrm{LC}$ & $\mathrm{LC}$ \\
\hline 170 & Blue-fronted Redstart & $\begin{array}{l}\text { Phoenicurus } \\
\text { frontalis }\end{array}$ & $\begin{array}{l}\text { Winter } \\
\text { migrant }\end{array}$ & $\mathrm{LC}$ & $\mathrm{LC}$ \\
\hline 171 & Blue-capped Redstart & $\begin{array}{l}\text { Phoenicurus } \\
\text { coeruleocephala }\end{array}$ & $\begin{array}{l}\text { Winter } \\
\text { migrant }\end{array}$ & $\mathrm{LC}$ & $\mathrm{LC}$ \\
\hline 172 & Common Stonechat & $\begin{array}{l}\text { Saxicola } \\
\text { torquatus }\end{array}$ & $\begin{array}{l}\text { Passage } \\
\text { migrant }\end{array}$ & $\mathrm{LC}$ & $\mathrm{LC}$ \\
\hline 173 & Pied Bushchat & Saxicola caprata & Resident & $\mathrm{LC}$ & $\mathrm{LC}$ \\
\hline 174 & Grey Bushchat & Saxicola ferreus & Resident & LC & $\mathrm{LC}$ \\
\hline \multirow[t]{2}{*}{175} & Himalayan Bush-robin & $\begin{array}{l}\text { Tarsiger } \\
\text { rufilatus }\end{array}$ & Resident & $\mathrm{LC}$ & $\mathrm{LC}$ \\
\hline & Chloropseidae & & & & \\
\hline \multirow[t]{2}{*}{176} & $\begin{array}{l}\text { Orange-bellied } \\
\text { Leafbird }\end{array}$ & $\begin{array}{l}\text { Chloropsis } \\
\text { hardwickii }\end{array}$ & Resident & $\mathrm{LC}$ & $\mathrm{LC}$ \\
\hline & Dicaeidae & & & & \\
\hline 177 & Plain Flowerpecker & $\begin{array}{l}\text { Dicaeum } \\
\text { minullum }\end{array}$ & Resident & $\mathrm{LC}$ & $\mathrm{LC}$ \\
\hline \multirow[t]{2}{*}{178} & $\begin{array}{l}\text { Fire-breasted } \\
\text { Flowerpecker }\end{array}$ & $\begin{array}{l}\text { Dicaeum } \\
\text { ignipectus }\end{array}$ & Resident & $\mathrm{LC}$ & $\mathrm{LC}$ \\
\hline & Nectariniidae & & & & \\
\hline 179 & Green-tailed Sunbird & $\begin{array}{l}\text { Aethopyga } \\
\text { nipalensis }\end{array}$ & Resident & $\mathrm{LC}$ & $\mathrm{LC}$ \\
\hline 180 & $\begin{array}{l}\text { Black-throated } \\
\text { Sunbird }\end{array}$ & $\begin{array}{l}\text { Aethopyga } \\
\text { saturate }\end{array}$ & Resident & $\mathrm{LC}$ & $\mathrm{LC}$ \\
\hline 181 & Crimson Sunbird & $\begin{array}{l}\text { Aethopyga } \\
\text { siparaja }\end{array}$ & Resident & $\mathrm{LC}$ & $\mathrm{LC}$ \\
\hline \multirow[t]{2}{*}{182} & Fire-tailed Sunbird & $\begin{array}{l}\text { Aethopyga } \\
\text { ignicauda }\end{array}$ & $\begin{array}{l}\text { Summer } \\
\text { migrant }\end{array}$ & $\mathrm{LC}$ & $\mathrm{LC}$ \\
\hline & Ploceidae & & & & \\
\hline \multirow[t]{2}{*}{183} & Baya Weaver & $\begin{array}{l}\text { Ploceus } \\
\text { philippinus }\end{array}$ & $\begin{array}{l}\text { Summer } \\
\text { migrant }\end{array}$ & $\mathrm{LC}$ & $\mathrm{LC}$ \\
\hline & Estrildidae & & & & \\
\hline 184 & Scaly-breasted Munia & $\begin{array}{l}\text { Lonchura } \\
\text { punctulata }\end{array}$ & Resident & LC & $\mathrm{LC}$ \\
\hline
\end{tabular}


Hem Bahadur Katuwal et Al. - Wildlife Assessment ofthe Chandragiri Hills, Kathmandu

\begin{tabular}{|c|c|c|c|c|c|}
\hline 185 & White-rumped Munia & Lonchura striata & $\begin{array}{l}\text { Summer } \\
\text { migrant }\end{array}$ & $\mathrm{LC}$ & $\mathrm{LC}$ \\
\hline & Passeridae & & & & \\
\hline 186 & House Sparrow & $\begin{array}{l}\text { Passer } \\
\text { domesticus }\end{array}$ & Resident & $\mathrm{LC}$ & $\mathrm{LC}$ \\
\hline \multirow[t]{2}{*}{187} & Eurasian Tree Sparrow & Passer montanus & Resident & $\mathrm{LC}$ & $\mathrm{LC}$ \\
\hline & Motacillidae & & & & \\
\hline 188 & Paddyfield Pipit & Anthus rufulus & Resident & $\mathrm{LC}$ & $\mathrm{LC}$ \\
\hline 189 & Rosy Pipit & Anthus roseatus & Resident & $\mathrm{LC}$ & $\mathrm{LC}$ \\
\hline 190 & Olive-backed Pipit & Anthus hodgsoni & $\begin{array}{l}\text { Winter } \\
\text { migrant }\end{array}$ & $\mathrm{LC}$ & $\mathrm{LC}$ \\
\hline 191 & Grey Wagtail & $\begin{array}{l}\text { Motacilla } \\
\text { cinerea }\end{array}$ & $\begin{array}{l}\text { Winter } \\
\text { migrant }\end{array}$ & $\mathrm{LC}$ & $\mathrm{LC}$ \\
\hline 192 & White-browed Wagtail & $\begin{array}{l}\text { Motacilla } \\
\text { maderaspatensis }\end{array}$ & $\begin{array}{l}\text { Summer } \\
\text { migrant }\end{array}$ & $\mathrm{LC}$ & $\mathrm{LC}$ \\
\hline \multirow[t]{2}{*}{193} & White Wagtail & Motacilla alba & $\begin{array}{l}\text { Winter } \\
\text { migrant }\end{array}$ & $\mathrm{LC}$ & $\mathrm{LC}$ \\
\hline & Fringillidae & & & & \\
\hline 194 & Common Rosefinch & $\begin{array}{l}\text { Carpodacus } \\
\text { erythrinus }\end{array}$ & $\begin{array}{l}\text { Winter } \\
\text { migrant }\end{array}$ & $\mathrm{LC}$ & $\mathrm{LC}$ \\
\hline 195 & Beautiful Rosefinch & $\begin{array}{l}\text { Carpodacus } \\
\text { pulcherrimus }\end{array}$ & $\begin{array}{l}\text { Winter } \\
\text { migrant }\end{array}$ & $\mathrm{LC}$ & $\mathrm{LC}$ \\
\hline 196 & $\begin{array}{l}\text { Dark-breasted } \\
\text { Rosefinch }\end{array}$ & $\begin{array}{l}\text { Procarduelis } \\
\text { nipalensis }\end{array}$ & $\begin{array}{l}\text { Winter } \\
\text { migrant }\end{array}$ & $\mathrm{LC}$ & $\mathrm{LC}$ \\
\hline 197 & $\begin{array}{l}\text { Yellow-breasted } \\
\text { Greenfinch }\end{array}$ & $\begin{array}{l}\text { Chloris } \\
\text { spinoides }\end{array}$ & $\begin{array}{l}\text { Winter } \\
\text { migrant }\end{array}$ & $\mathrm{LC}$ & $\mathrm{LC}$ \\
\hline \multirow[t]{2}{*}{198} & Gold-naped Finch & $\begin{array}{l}\text { Pyrrhoplectes } \\
\text { epaulette }\end{array}$ & $\begin{array}{l}\text { Winter } \\
\text { migrant }\end{array}$ & VU & $\mathrm{LC}$ \\
\hline & Emberizidae & & & & \\
\hline 199 & Crested Bunting & $\begin{array}{l}\text { Emberiza } \\
\text { lathami }\end{array}$ & $\begin{array}{l}\text { Summer } \\
\text { migrant }\end{array}$ & $\mathrm{LC}$ & $\mathrm{LC}$ \\
\hline
\end{tabular}


Appendix 4: Herpetofauna recorded in Chandragiri Hills where LC is Least Concern, VU is Vulnerable.

\begin{tabular}{|c|c|c|c|c|c|}
\hline \multirow{2}{*}{ S.N. } & \multirow{2}{*}{$\begin{array}{l}\text { Class/Order/Family/Com } \\
\text { mon Names }\end{array}$} & \multirow[b]{2}{*}{ Scientific Name } & \multicolumn{2}{|c|}{ Conservation Status } & \multirow{2}{*}{ CITES } \\
\hline & & & IUCN & National & \\
\hline & Amphibia & & & & \\
\hline & Anura & & & & \\
\hline & Bufonidae & & & & \\
\hline 1 & Himalayan Toad & $\begin{array}{l}\text { Duttaphrynus } \\
\text { himalayanus }\end{array}$ & $\mathrm{LC}$ & & \\
\hline 2 & Black-spined Toad & $\begin{array}{l}\text { Duttaphrynus } \\
\text { melanostictus }\end{array}$ & $\mathrm{LC}$ & & \\
\hline \multirow[t]{2}{*}{3} & Marbled Toad & Bufo stomaticus & $\mathrm{LC}$ & & \\
\hline & Microhylidae & & & & \\
\hline \multirow[t]{2}{*}{4} & Narrow-mouthed Frog & Microhyla ornata & $\mathrm{LC}$ & & \\
\hline & Megophryidae & & & & \\
\hline \multirow[t]{2}{*}{5} & Myanmar Pelobatid Toad & Megophrys parva & $\mathrm{LC}$ & & \\
\hline & Ranidae & & & & \\
\hline 6 & Skittering Frog & $\begin{array}{l}\text { Euphlyctis } \\
\text { cyanophlyctis }\end{array}$ & $\mathrm{LC}$ & & \\
\hline 7 & Indian Bull Frog & $\begin{array}{l}\text { Hoplobatrachus } \\
\text { tigerinus }\end{array}$ & $\mathrm{LC}$ & & \\
\hline 8 & Nepalese Cricket Frog & $\begin{array}{l}\text { Fejervarya } \\
\text { nepalensis }\end{array}$ & $\mathrm{LC}$ & & \\
\hline \multirow[t]{2}{*}{9} & Indian Burrowing Frog & $\begin{array}{l}\text { Sphaerotheca } \\
\text { breviceps }\end{array}$ & $\mathrm{LC}$ & & \\
\hline & Rhacophoridae & & & & \\
\hline \multirow[t]{4}{*}{10} & $\begin{array}{lr}\text { Java } & \text { Whipping } \\
\text { Frog/Common Tree Frog } \\
\end{array}$ & $\begin{array}{l}\text { Polypedates } \\
\text { leucomystax }\end{array}$ & $\mathrm{LC}$ & & \\
\hline & Reptilia & & & & \\
\hline & Squamata & & & & \\
\hline & Agamidae & & & & \\
\hline 11 & Common Garden Lizard & Calotes versicolor & & & \\
\hline 12 & $\begin{array}{l}\text { Three Keeled Mountain } \\
\text { Lizard }\end{array}$ & $\begin{array}{l}\text { Japalura } \\
\text { tricarinata }\end{array}$ & $\mathrm{LC}$ & & \\
\hline 13 & $\begin{array}{l}\text { Variegated Mountain } \\
\text { Lizard }\end{array}$ & $\begin{array}{l}\text { Japalura } \\
\text { variegata } \\
\end{array}$ & & & \\
\hline \multirow[t]{2}{*}{14} & Kashmiri Rock Agama & $\begin{array}{l}\text { Laudakia } \\
\text { tuberculata }\end{array}$ & & & \\
\hline & Scincidae & & & & \\
\hline 15 & Brahminy Skink & Eutropis carinata & $\mathrm{LC}$ & & \\
\hline 16 & Spotted Forest Skink & $\begin{array}{l}\text { Sphenomorphus } \\
\text { maculatus }\end{array}$ & & & \\
\hline \multirow[t]{2}{*}{17} & Sikkim Skink & $\begin{array}{l}\text { Asymblepharus } \\
\text { sikimmensis }\end{array}$ & & & \\
\hline & Varanidae & & & & \\
\hline \multirow[t]{2}{*}{18} & Bengal Monitor Lizard & $\begin{array}{l}\text { Varanus } \\
\text { bengalensis }\end{array}$ & $\mathrm{LC}$ & Susceptible & $\mathrm{I}$ \\
\hline & Typhlopidae & & & & \\
\hline 19 & Brahminy Blind Snake & Indotyphlops & & & \\
\hline
\end{tabular}


Hem Bahadur Katuwal et al. - Wildlife Assessment ofthe Chandragiri Hills, Kathmandu

\begin{tabular}{|c|c|c|c|c|c|}
\hline & & braminus & & & \\
\hline & Colubridae & & & & \\
\hline 20 & Boulenger's Kellback & $\begin{array}{l}\text { Amphiesma } \\
\text { parallelum }\end{array}$ & & & \\
\hline 21 & Himalayan Keelback & $\begin{array}{l}\text { Amphiesma } \\
\text { platyceps }\end{array}$ & & & \\
\hline 22 & Buff-striped Keelback & $\begin{array}{l}\text { Amphiesma } \\
\text { stolatum }\end{array}$ & & & \\
\hline 23 & Common Trinket Snake & $\begin{array}{l}\text { Coelognathus } \\
\text { helena }\end{array}$ & & & \\
\hline 24 & $\begin{array}{ll}\text { Copper-headed } & \text { Trinket } \\
\text { Snake } & \\
\end{array}$ & $\begin{array}{l}\text { Coelognathus } \\
\text { radiatus }\end{array}$ & & & \\
\hline 25 & $\begin{array}{ll}\text { Common } & \text { Bronzeback } \\
\text { Tree Snake } & \\
\end{array}$ & $\begin{array}{l}\text { Dendrelaphis } \\
\text { tristis }\end{array}$ & & & \\
\hline 26 & $\begin{array}{ll}\text { Himalayan } & \text { Trinket } \\
\text { Snake } & \\
\end{array}$ & $\begin{array}{l}\text { Orthriophis } \\
\text { hodgsoni }\end{array}$ & & & \\
\hline 27 & Common Wolf Snake & Lycodon aulicus & & & \\
\hline 28 & Indian Rat Snake & Ptyas mucosa & & Susceptible & II \\
\hline \multirow[t]{2}{*}{29} & Darjeeling Worm Snake & $\begin{array}{l}\text { Trachischium } \\
\text { fuscum }\end{array}$ & & & \\
\hline & Elapidae & & & & \\
\hline 30 & Indian/Common Cobra & Naja naja & & & II \\
\hline 31 & Monocled Cobra & Naja kaouthia & $\mathrm{LC}$ & & II \\
\hline \multirow[t]{2}{*}{32} & King Cobra & $\begin{array}{l}\text { Ophiophagus } \\
\text { hannah }\end{array}$ & VU & VU & II \\
\hline & Viperidae & & & & \\
\hline 33 & Mountain Pit Viper & Ovophis monticola & $\mathrm{LC}$ & & \\
\hline 34 & White-lipped Pit Viper & $\begin{array}{l}\text { Trimeresurus } \\
\text { albolabris }\end{array}$ & $\mathrm{LC}$ & & \\
\hline
\end{tabular}


Appendix 5: Butterfly recorded in Chandragiri Hills, where LC is Least Concern, VU is Vulnerable.

\begin{tabular}{|c|c|c|c|c|c|}
\hline \multirow{2}{*}{ S.N. } & \multirow{2}{*}{$\begin{array}{l}\text { Order/Family/Co } \\
\text { mmon Name }\end{array}$} & \multirow{2}{*}{ Scientific Name } & \multicolumn{2}{|c|}{ Conservation Status } & \multirow{2}{*}{ CITES } \\
\hline & & & IUCN & National & \\
\hline & Lepidoptera & & & & \\
\hline & Nymphalidae & & & & \\
\hline 1. & Common Tiger & Danaus genutia & & & \\
\hline 2. & Glassy Tiger & Parantica aglea & & & \\
\hline 3. & $\begin{array}{l}\text { Striped Blue } \\
\text { Crow }\end{array}$ & Euploea mulciber & & & \\
\hline 4. & Chocolate Pansy & Junonia iphita & & & \\
\hline 5. & Yellow Pansy & Junonia hierta & & & \\
\hline 6. & Lemon Pansy & Junonia orithya & & & \\
\hline 7. & Peacock Pansy & Junonia almanac & & & \\
\hline 8. & Common Earl & Tanaecia julii & & & \\
\hline 9. & Grey Count & Tanaecia lepidea & & & \\
\hline 10. & Common Lascar & Pantoporia hordonia & & & \\
\hline 11. & Yellow Coster & Acraea issoria & & & \\
\hline 12. & Common Leopard & Phalanta phalantha & & & \\
\hline 13. & Common Map & Cyrestis thyodamas & & & \\
\hline 14. & Common Sailor & Neptis hylas & & & \\
\hline 15. & Common Sergeant & Athyma perius & & & \\
\hline 16. & Eastern Courtier & Sephisa Chandra & & & \\
\hline 17. & Grand Duchess & Euthalia patala & & & \\
\hline 18. & $\begin{array}{l}\text { Himalayan } \\
\text { Sergeant }\end{array}$ & Athyma opalina & & & \\
\hline 19. & Indian Fritillary & Argyreus hyperbius & & & \\
\hline 20. & $\begin{array}{l}\text { Indian Red } \\
\text { Admiral }\end{array}$ & Vanessa indica & & & \\
\hline 21. & $\begin{array}{l}\text { Indian } \\
\text { Tortoiseshell }\end{array}$ & Aglais cashmirensis & & & \\
\hline 22. & Large Silverstripe & Childrena childreni & & & \\
\hline 23. & Painted Lady & Vanessa cardui & LC & & \\
\hline 24. & Red Lacewing & Cethosia bibilis & & & \\
\hline 25. & Himalayan Jester & Symbrenthia hypselis & & & \\
\hline 25. & $\begin{array}{l}\text { Orange Staff } \\
\text { Sergeant }\end{array}$ & Athyma cama & & & \\
\hline 27. & Colour Sergeant & Athyma nefte & & & \\
\hline 28. & Vagrant & Vagrant egista & $\mathrm{LC}$ & & \\
\hline 29. & Common Siren & Hestina persimilis & & VU & \\
\hline 30. & $\begin{array}{l}\text { Indian } \\
\text { Commodore }\end{array}$ & Auzakia danava & & & \\
\hline 31. & Great Eggfly & Hypolymnas bolina & & & \\
\hline 32. & Bluetail Jester & Symbrenthia niphanda & & & \\
\hline 33. & Common Castor & Ariadne merione & & & \\
\hline
\end{tabular}




\begin{tabular}{|c|c|c|c|c|c|}
\hline 34. & Gray Pansy & Precis atlites & & & \\
\hline 35. & Bhutan Sergeant & Athyma jina & & & \\
\hline 36. & $\begin{array}{l}\text { White } \\
\text { Commodore }\end{array}$ & Limenitis dudu & & & \\
\hline 37. & Yellow Sailor & Neptis ananta & & & \\
\hline 38. & $\begin{array}{l}\text { Banded } \\
\text { Treebrown }\end{array}$ & Lethe confusa & & & \\
\hline 39. & $\begin{array}{l}\text { Himalayan } \\
\text { Fivering }\end{array}$ & Ypthima sakra & & & \\
\hline 40. & Common Fivering & Ypthima baldus & & & \\
\hline 41. & Large Three Ring & Ypthima nereda & & & \\
\hline 42. & $\begin{array}{l}\text { Newar Three- } \\
\text { Ring }\end{array}$ & Ypthima newara & & & \\
\hline \multirow[t]{2}{*}{43.} & Tiger Brown & Orinoma damaris & & & \\
\hline & Lycaenidae & & & & \\
\hline 44. & Peablue & Lampides boeticus & & & \\
\hline 45. & Purple Sapphire & Heliophorus epicles & & & \\
\hline 46. & $\begin{array}{l}\text { Silver Grey- } \\
\text { Silver Line }\end{array}$ & Spindasis nipalicus & & & \\
\hline 47. & $\begin{array}{l}\text { Common } \\
\text { Hedgeblue }\end{array}$ & Actyolepis puspa & & & \\
\hline 48. & Large Hedge Blue & Celastrina huegeli & & & \\
\hline 49. & $\begin{array}{l}\text { Common } \\
\text { Cerulean }\end{array}$ & Jamides celeno & & & \\
\hline 50. & Dark Grassblue & Zizeeria karsandra & & & \\
\hline \multirow[t]{2}{*}{51.} & Pale Grass Blue & Pseudozizeeria maha & & & \\
\hline & Riodiniidae & & & & \\
\hline 52. & $\begin{array}{l}\text { Double Banded } \\
\text { Judy }\end{array}$ & Abisara bifasciata & & & \\
\hline 53. & Dark Judy & Abisara fylla & & & \\
\hline 54. & Punchinello & Zemoros flegyas & & & \\
\hline 55. & Striped Punch & Dodona adonira & & & \\
\hline 56. & Tailed Punch & Dodona eugenes & & & \\
\hline 57. & Lesser Punch & Dodona dipoea & & & \\
\hline \multirow[t]{2}{*}{58.} & Plum Judy & Abisara echerius & & & \\
\hline & Papilionidae & & & & \\
\hline 59. & $\begin{array}{l}\text { Common } \\
\text { Bluebottle }\end{array}$ & Graphium serpedon & $\mathrm{LC}$ & & \\
\hline 60. & Common Mormon & Papilio polytes & $\mathrm{LC}$ & & \\
\hline 61. & Common Mime & Chilasa clytia dissimilis & $\mathrm{LC}$ & & \\
\hline 62. & Golden Birdwing & Troides aeacus & $\mathrm{LC}$ & Susceptible & II \\
\hline 63. & Paris Peacock & Papilio paris & $\mathrm{LC}$ & & \\
\hline 64. & Rose Windmill & Byasa latreillei & $\mathrm{LC}$ & & \\
\hline 65. & Spangle & Papilio protenor & LC & & \\
\hline 66. & Tailed Jay & Graphium agamemnon & $\mathrm{LC}$ & & \\
\hline
\end{tabular}


Hem Bahadur Katuwal et al. - Wildlife Assessment ofthe Chandragiri Hills, Kathmandu

\begin{tabular}{|l|l|l|l|l|l|}
\hline 67. & Glassy Bluebottle & Graphium cloanthus & LC & & \\
\hline 68. & Lime Swallowtail & Papilio demoleus & LC & & \\
\hline 69. & Common Peacock & Papilio polyctor & LC & & \\
\hline 70. & Red Helen & Papilio helenus & LC & & \\
\hline 71. & Great Mormon & Papilio memnon & LC & & \\
\hline & Pieridae & & & & \\
\hline 72. & Great Blackvein & Metaporia agathon & & & \\
\hline 73. & $\begin{array}{l}\text { Common } \\
\text { Emigrant }\end{array}$ & Catopsilia pomona & & & \\
\hline 74. & $\begin{array}{l}\text { Indian Cabbage } \\
\text { White }\end{array}$ & Pieris canidia & & & \\
\hline 75. & $\begin{array}{l}\text { Dark Clouded } \\
\text { Yellow }\end{array}$ & Colias fieldii & & & \\
\hline 76. & Hill Jezebel & Delias belladonna & & & \\
\hline & Hesperiidae & & & & \\
\hline 77. & Fulvous Pied Flat & Pseudocoladenia dan & & & \\
\hline
\end{tabular}

